\title{
Molecular composition of dicarboxylic acids, ketocarboxylic acids, $\alpha$-dicarbonyls and fatty acids in atmospheric aerosols from Tanzania, East Africa during wet and dry seasons
}

\author{
S. L. Mkoma ${ }^{1,2}$ and K. Kawamura ${ }^{1}$ \\ ${ }^{1}$ Institute of Low Temperature Science, Hokkaido University, N19 W08, Kita-ku, Sapporo 060-0819, Japan \\ ${ }^{2}$ Department of Physical Sciences, Faculty of Science, Sokoine University of Agriculture, P.O. Box 3038, \\ Chuo Kikuu, Morogoro, Tanzania
}

Correspondence to: S. L. Mkoma (stelyusm@gmail.com)

Received: 21 August 2012 - Published in Atmos. Chem. Phys. Discuss.: 27 September 2012 Revised: 9 February 2013 - Accepted: 12 February 2013 - Published: 26 February 2013

\begin{abstract}
Atmospheric aerosol samples of $\mathrm{PM}_{2.5}$ and $\mathrm{PM}_{10}$ were collected during the wet and dry seasons in 2011 from a rural site in Tanzania and analysed for water-soluble dicarboxylic acids, ketocarboxylic acids, $\alpha$-dicarbonyls, and fatty acids using a gas chromatography/flame ionization detector (GC/FID) and GC/mass spectrometry. Here we report the molecular composition and sources of diacids and related compounds for wet and dry seasons. Oxalic acid $\left(\mathrm{C}_{2}\right)$ was found as the most abundant diacid species followed by succinic and/or malonic acids whereas glyoxylic acid and glyoxal were the dominant ketoacid and $\alpha$ dicarbonyl, respectively in both seasons in $\mathrm{PM}_{2.5}$ and $\mathrm{PM}_{10}$. Mean concentration of $\mathrm{C}_{2}$ in $\mathrm{PM}_{2.5}\left(121 \pm 47 \mathrm{ng} \mathrm{m}^{-3}\right)$ was lower in wet season than dry season $\left(258 \pm 69 \mathrm{ng} \mathrm{m}^{-3}\right)$. Similarly, $\mathrm{PM}_{10}$ samples showed lower concentration of $C_{2} \quad\left(169 \pm 42 \mathrm{ng} \mathrm{m}^{-3}\right)$ in wet season than dry season $\left(292 \pm 165 \mathrm{ng} \mathrm{m}^{-3}\right)$. Relative abundances of $\mathrm{C}_{2}$ in total diacids were $65 \%$ and $67 \%$ in $\mathrm{PM}_{2.5}$ and $65 \%$ and $64 \%$ in $\mathrm{PM}_{10}$ in the wet and dry seasons, respectively. Total concentrations of diacids $\left(289-362 \mathrm{ng} \mathrm{m}^{-3}\right.$ ), ketoacids (37.8$53.7 \mathrm{ng} \mathrm{m}^{-3}$ ), and $\alpha$-dicarbonyls (5.7-7.8 $\mathrm{ng} \mathrm{m}^{-3}$ ) in Tanzania are higher than those reported at a rural background site in Nylsvley (South Africa) but comparable or lower than those reported from sites in Asia and Europe. Diacids and ketoacids were found to be present mainly in $\mathrm{PM}_{2.5}$ in both seasons (total $\alpha$-dicarbonyls in the dry season), suggesting a production of organic acids from pyrogenic sources and photochemical oxidations. Averaged contributions of total diacids to aerosol total carbon were $1.4 \%$ in $\mathrm{PM}_{2.5}$ and $2.1 \%$
\end{abstract}

in $\mathrm{PM}_{10}$ during wet season and $3.3 \%$ in $\mathrm{PM}_{2.5}$ and $3.9 \%$ in $\mathrm{PM}_{10}$ during dry season whereas those to water-soluble organic carbon were $2.2 \%$ and $4.7 \%$ in $\mathrm{PM}_{2.5}$ during wet season and $3.1 \%$ and $5.8 \%$ in $\mathrm{PM}_{10}$ during dry season. The higher ratios in dry season suggest an enhanced photochemical oxidation of organic precursors probably via heterogeneous reactions on aerosols under strong solar radiation. Strong positive correlations were found among diacids and related compounds as well as good relations to source tracers in both seasons, suggesting a mixed source from natural biogenic emissions, biomass burning, biofuel combustion, and photochemical production.

\section{Introduction}

Low molecular weight dicarboxylic acids, ketoacids and $\alpha$-dicarbonyls are important components that contribute to water-soluble organic carbon (WSOC) in aerosol particles (Simoneit et al., 2004; H. Wang et al., 2006; Kawamura et al., 2010). Dicarboxylic acids and related compounds have been reported to influence on human health (Highwood and Kinnersley, 2006), hygroscopic property of aerosols (McFiggans et al., 2005), and contribute to the cloud condensation nuclei (CCN) activity (Gierlus et al., 2012). Changes in chemical composition and $\mathrm{CCN}$ activity can alter the optical properties of aerosol particles (Reid et al., 1998) and affects cloud microphysical properties and hence precipitation patterns and cloud albedo (Reid et al., 1998; Ramanathan et al., 2001). 
Dicarboxylic acids and related compounds are derived from primary sources and secondarily produced from different precursor species via photochemical reactions. Biomass burning (Gao et al., 2003; Falkovich et al., 2005; Kundu et al., 2010a) and fossil fuel combustion (Kawamura and Kaplan, 1987; Ho et al., 2006) are major primary sources. Photochemical-oxidation of biogenic unsaturated fatty acids (Kawamura and Gagosian, 1987), volatile organic compounds (VOCs) from biogenic and anthropogenic emissions, and aromatic hydrocarbons and cyclic olefins (Kawamura et al., 1996a) are important secondary sources. Atmospheric loadings of organic aerosols are significantly influenced by primary emissions from biomass burning and secondary productions (Claeys et al., 2004; G. Wang et al., 2006; Carlton et al., 2006). Recently, emission of isoprene and other biogenic VOCs followed by the subsequent oxidation in the atmosphere has been proposed as an important source of oxalic acid (Myriokefalitakis et al., 2011). Isoprene is the most important biogenic VOC emitted from higher plants (Guenther et al., 2006).

In Tanzania, biomass/wood fuels accounts for major source of energy providing up to $90 \%$ of the total national energy consumption with $8 \%$ from petroleum products and $1.2 \%$ from electricity (URT, 2003). Burning of biofuels such as wood, charcoal, and agricultural waste is the main energy source in this country. Charcoal burning for cooking is very common not only in rural areas but also in cities. On the other hand, dumping of domestic and municipal solid waste into open landfills and the subsequent uncontrolled open burning are common in the country. Therefore, photochemical reactions together with anthropogenic biofuel combustion produce various organic species including dicarboxylic acids and related compounds to form atmospheric particles, leading to the deterioration of the air quality in Tanzania.

Studies have reported that dicarboxylic acids and related compounds are ubiquitously present in the atmospheric aerosols from various environments in continental rural and urban (Limbeck et al., 2001, 2005; Kerminen et al., 2000; Kawamura and Yasui, 2005; Ho et al., 2006; Hsieh et al., 2008; Hyder et al., 2012; Wang et al., 2012), coastal and remote marine (Kawamura and Sakaguchi, 1999; Mochida et al., 2007; Rinaldi et al., 2011), and polar sites (Kawamura et al., 1996b, 2010, 2012; Narukawa et al., 2003). However, little is known about organic acids in tropical Africa and no extensive studies of both organic and inorganic species have been conducted in Africa (Simoneit et al., 1988; Cachier et al., 1991, 1995; Limbeck and Puxbaum, 1999; Limbeck et al., 2001; Gao et al., 2003). Here we report for the first time the molecular composition of dicarboxylic acids, ketocarboxylic acids, $\alpha$-dicarbonyls and fatty acids in aerosols from a rural background site in Tanzania, East Africa and discuss their size distributions, seasonal variations, sources and formation pathways.

\section{Experimental}

\subsection{Site description}

Aerosol sampling was carried out at a typical rural site in Morogoro $\left(06^{\circ} 47^{\prime} 40.8^{\prime \prime} \mathrm{S}, 37^{\circ} 37^{\prime} 44.5^{\prime \prime} \mathrm{E}\right.$, altitude $504 \mathrm{~m}$ a.s.l), located about $200 \mathrm{~km}$ west of the Indian Ocean, and the city of Dar es Salaam, a business capital in Tanzania. The site lies at the base of Uluguru Mountains, which rise to $2648 \mathrm{~m}$ a.s.l. and are characterised as residential area with small-scale agricultural fields (cereal crops), and cattle grazing fields. Like in most other developing countries where poverty is concentrated in rural areas, Tanzania with a population of 42.7 million people (July 2011, estimates) has $25 \%$ of its population living below basic needs poverty line (2008 estimate). Their main sources of fuel for domestic cooking and heating are wood and charcoal.

\subsection{Aerosol sampling}

Aerosol samples of $\mathrm{PM}_{2.5}$ and $\mathrm{PM}_{10}$ were collected using low volume samplers (Gent type, flow rate $17.0 \mathrm{~L} \mathrm{~min}^{-1}$ ) in parallel (Maenhaut et al., 1994) in the 2011 wet and dry seasons. The samplers were placed at a fenced meteorological observatory located at Solomon Mahlangu campus of Sokoine University of Agriculture. Aerosol collection was performed approximately at $2.7 \mathrm{~m}$ above the ground level using quartz fibre filters (Pallflex 2500QAT-UP, $47 \mathrm{~mm}$ ), which were pre-baked at $450^{\circ} \mathrm{C}$ for $4 \mathrm{~h}$ in a furnace to eliminate adsorbed organics before use. A total of 21 sets of actual samples were collected using each sampler on approximately $24 \mathrm{~h}$ basis (exchange of filters was done at 07:30 a.m.). Two field blank sets were collected without pumping air. Before and after sampling the filters were placed in a pre-heated glass vial with a Teflon-lined screw cap and kept frozen at $-20^{\circ} \mathrm{C}$ during storage. The samples were transported to the atmospheric chemistry laboratory at the Institute of Low Temperature Sciences (ILTS), Hokkaido University (Japan), where the samples were stored at $-20^{\circ} \mathrm{C}$ prior to analysis. All the analytical procedures were strictly quality-controlled to avoid any possible contamination of the samples.

\subsection{Chemical analysis}

Filter samples were analyzed for water-soluble dicarboxylic acids, ketocarboxylic acids, $\alpha$-dicarbonyls and fatty acids using the method reported by Kawamura and Ikushima (1993) and Ho et al. (2010). Briefly, a $1.54 \mathrm{~cm}^{2}$ punch of each quartz fibre filter was extracted three times with $10 \mathrm{~mL}$ ultra pure organic-free water (resistivity of $>18.2 \mathrm{M} \Omega \mathrm{cm}$ ) under ultrasonication for $10 \mathrm{~min}$. To remove insoluble particles and filter debris, the extracts were passed through a glass column (Pasteur pipette) packed with quartz wool. The $\mathrm{pH}$ of the extracts were adjusted to 8.5-9.0 with $0.1 \mathrm{M} \mathrm{KOH}$ (potassium hydroxide) solution, concentrated almost to dryness using a rotary evaporator under vacuum and then derivatized to 


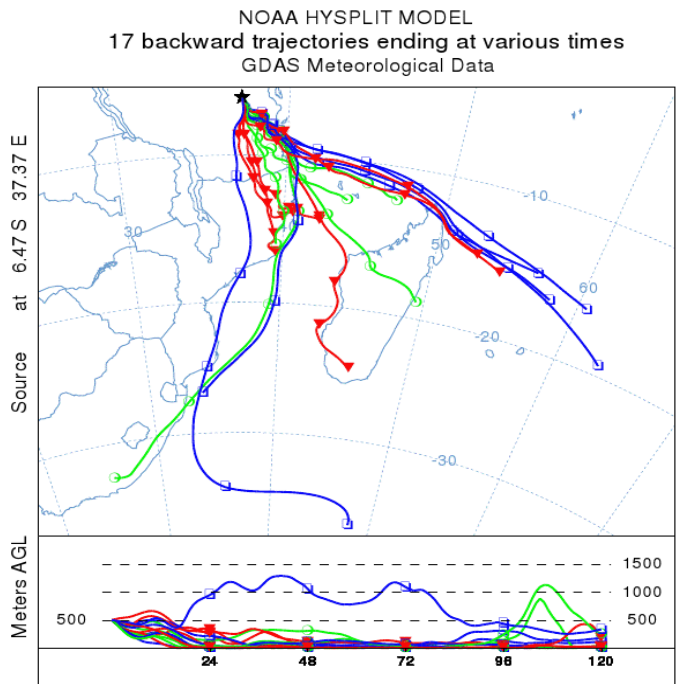

Wet season

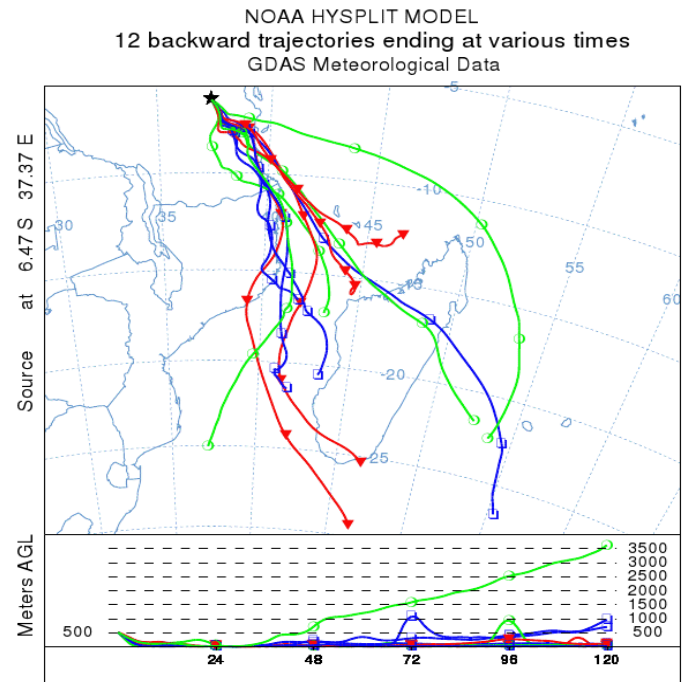

Dry season

Fig. 1. Five-day backward air mass back trajectories arriving at Morogoro during the wet and dry seasons.

dibutyl ester (for carboxyl group) and dibutoxy acetals (for keto group) with $14 \%$ boron trifluoride $\left(\mathrm{BF}_{3}\right) / n$-butanol at $100^{\circ} \mathrm{C}$ for $1 \mathrm{~h}$. The derived esters and acetals were dissolved in $n$-hexane, washed with pure water three times and the extracts were again concentrated using rotary evaporator under vacuum. After nitrogen blow down to near dryness, $n$-hexane $(100 \mu \mathrm{L})$ was added and the derivatives were analyzed using a capillary gas chromatograph (GC; HP 6890) installed with a flame ionization detector (FID). Peaks were identified by comparing GC retention time with authentic standards and confirmed by mass spectral examination using a gas chromatography/mass spectrometer (GC/MS).

Recovery experiments were performed by spiking authentic standards to a pre-combusted quartz fibre filter. The recoveries were 81 to $88 \%$ for oxalic acid and more than $92 \%$ for malonic, succinic, glutaric, and adipic acids. Following the same analytical procedure in our laboratory, recoveries for glyoxylic acid, pyruvic acid and methylglyoxal were reported to be $88 \%, 72 \%$ and $47 \%$, respectively (Kawamura and Yasui, 2005). Reproducibility of filter sample was within $4 \%$ for major species. GC chromatograms of field blanks showed small peaks for oxalic, malonic, phthalic, and glyoxylic acids, however, they were less than $1 \%$ (oxalic acid), $3 \%$ (malonic acid), $8 \%$ (phthalic acid) and 5\% (glyoxylic acid) of real samples. All the reported concentrations of diacids and related compounds are corrected for the field blanks. Details for measurement of gravimetric aerosol mass and analyses of total carbon (TC), organic carbon (OC), elemental carbon (EC), water-soluble organic carbon (WSOC), levoglucosan and water-soluble inorganic ions are described elsewhere (Mkoma et al., 2012).

\subsection{Meteorology and air mass trajectories}

Morogoro, where the sampling site locates, experiences a humid tropical savanna climate (TMA, 2011). The ambient temperature during the campaigns varied from 22.9 to $29.1^{\circ} \mathrm{C}$ (avg: $26.0 \pm 0.8^{\circ} \mathrm{C}$ ) in the wet season and $21.1-$ $28.2^{\circ} \mathrm{C}$ (avg.: $24.6 \pm 0.7^{\circ} \mathrm{C}$ ) in the dry season. The site is sensitive to frequent phenomenon of temperature inversion events due to its proximity to the foothill of the Uluguru Mountain ranges (Mkoma et al., 2009). The daily average relative humidity ranged from 65 to $96 \%$ (avg.: $81 \pm 0.7 \%$ ) in the morning hours and from 41 to $60 \%$ (avg.: $50 \pm 0.6 \%$ ) in the afternoon. In the wet season campaign (30 May to 13 June), there were only 4 days without rain. In contrast, there were only 2 rainy days in the dry season (28 July to $8 \mathrm{Au}-$ gust). However, the entire sampling period was rather dry and few aerosol samples were met with a very weak rain. The prevailing winds during both campaigns were the southeasterly (SE) monsoons with daily average wind speed of $4.1 \mathrm{~m} \mathrm{~s}^{-1}$ and $12 \mathrm{~m} \mathrm{~s}^{-1}$ in the wet and dry seasons, respectively.

To find out the possible source regions of air masses at Morogoro during the campaigns, we computed 5-day backward air mass trajectories at an altitude of $500 \mathrm{~m}$ for every $24 \mathrm{~h}$ using the Hybrid Single-Particle Lagrangian Integrated Trajectory (HYSPLIT) model from NOAA/ARL (Draxler and Rolph, 2012). The trajectory sectors showed similar transport pathways and source regions in both wet and dry seasons (Fig. 1). The air masses that arrived in Morogoro were mainly from the Indian Ocean over the continents in Madagascar, Mozambique or Tanzania. 


\section{Results and discussion}

\subsection{Molecular composition and seasonal variations of diacids and related compounds}

We determined diacids, ketoacids, $\alpha$-dicarbonyls, and fatty acids during the wet and dry seasons in $\mathrm{PM}_{2.5}$ and $\mathrm{PM}_{10}$ at a rural site in Tanzania (Table 1). The detected compounds were saturated straight chain diacids $\left(\mathrm{C}_{2}-\mathrm{C}_{9}\right)$, unsaturated aliphatic (maleic, fumaric, and methylmaleic), brached chain (methylmalonic, $\mathrm{iC}_{4}$ methylsuccinic, $\mathrm{iC}_{5}$ ) and aromatic (phthalic, isophthalic, and terephthalic acids) diacids, ketocarboxylic acids $\left(\omega \mathrm{C}_{2}-\omega \mathrm{C}_{9}\right.$ and pyruvic acid), $\alpha$-dicarbonyls (glyoxal and methylglyoxal), and fatty acids $\left(\mathrm{C}_{14}, \mathrm{C}_{16}, \mathrm{C}_{18}\right.$, $\mathrm{C}_{18: 1}, \mathrm{C}_{20}, \mathrm{C}_{22}$ and $\left.\mathrm{C}_{24}\right)$. Longer-chain diacids $\left(\mathrm{C}_{10}-\mathrm{C}_{12}\right)$ were below the detection limit (ca. $0.005 \mathrm{ng} \mathrm{m}^{-3}$ ) in all the samples.

Size distributions and average molecular compositions of diacids, ketoacids, $\alpha$-dicarbonyls and fatty acids in wet and dry seasons are shown in Figs. 2 and 3. Total concentrations of diacids ranged from $97-547 \mathrm{ng} \mathrm{m}^{-3}$ in $\mathrm{PM}_{2.5}$ and $165-959 \mathrm{ng} \mathrm{m}^{-3}$ in $\mathrm{PM}_{10}$. Oxalic acid $\left(\mathrm{C}_{2}\right)$ was the most abundant diacid followed by succinic $\left(\mathrm{C}_{4}\right)$ and/or malonic $\left(\mathrm{C}_{3}\right)$ acids in two seasons and sizes. Mean concentrations of $\mathrm{C}_{2}$ in $\mathrm{PM}_{2.5}$ were $121 \pm 47 \mathrm{ng} \mathrm{m}^{-3}$ during the wet season and $258 \pm 69 \mathrm{ng} \mathrm{m}^{-3}$ during the dry season whereas those in $\mathrm{PM}_{10}$ were $169 \pm 42 \mathrm{ng} \mathrm{m}^{-3}$ and $292 \pm 165 \mathrm{ng} \mathrm{m}^{-3}$ during the wet and dry seasons (Table 1). The relative abundances of individual diacids to total saturated straight-chain $\left(\mathrm{C}_{2}-\right.$ $\mathrm{C}_{9}$ ) diacids in $\mathrm{PM}_{2.5}$ and $\mathrm{PM}_{10}$ during the wet and dry seasons are shown in Fig. 4 as pie diagrams. The relative abundances of $\mathrm{C}_{2}$ in total diacids were $65 \%$ and $67 \%$ in $\mathrm{PM}_{2.5}$ and $65 \%$ and $64 \%$ in $\mathrm{PM}_{10}$ in the wet and dry seasons, respectively (Table 2 and Fig. 4). Other studies suggested that higher relative abundances of oxalic acid are caused by enhanced biomass burning activities (Narukawa et al., 1999), photochemical production (Ervens et al., 2004) and ageing of organic acids (Kawamura and Sakaguchi, 1999; Aggarwal and Kawamura, 2008). Predominance of oxalic acid in aerosol samples from background sites in Africa (Limbeck and Puxbaum, 1999; Limbeck et al., 2001) and continental sites affected by biomass burning (Gao et al., 2003; Kundu et al., 2010a) have been reported.

Concentrations of longer-chain diacids $\left(\mathrm{C}_{6}-\mathrm{C}_{9}\right)$ varied in different seasons and size fractions with suberic acid $\left(\mathrm{C}_{8}\right)$ being the most abundant in the wet season in $\mathrm{PM}_{2.5}$, adipic acid $\left(\mathrm{C}_{6}\right)$ and azelaic acid $\left(\mathrm{C}_{9}\right)$ in the dry season in $\mathrm{PM}_{2.5}$ and $\mathrm{C}_{9}$ in both seasons in $\mathrm{PM}_{10}$ (Fig. 4). Previous studies reported an enhanced production of $\mathrm{C}_{6}$ from the oxidation of anthropogenic cyclohexene (Kawamura and Ikushima, 1993) and of $\mathrm{C}_{9}$ from photochemical oxidation of biogenic unsaturated fatty acids (Kawamura and Gagosian, 1987). Phthalic acid $(\mathrm{Ph})$ and terephthalic acid (tPh) had high abundances in $\mathrm{PM}_{2.5}$ during the wet season and in $\mathrm{PM}_{10}$ during the dry season. The observed high abundances of these aro- matic diacids suggest anthropogenic effect from combustion sources (Kawamura and Kaplan, 1987) and/or atmospheric photochemical degradation of polycyclic aromatic hydrocarbons (Kawamura and Ikushima, 1993). In Tanzania, dumping of municipal solid waste (large amounts of plastics) into open landfills is very common and $60 \%$ of daily domestic solid waste are disposed and subjected to open burning (Kassim, 2006). Plastic burning under open-fire conditions and local anthropogenic emissions in both seasons should be responsible for these aromatic acids (Yassaa et al., 2001; Simoneit et al., 2005; Kawamura and Pavuluri, 2010).

Mean concentrations of total ketoacids were $31 \pm$ $18 \mathrm{ng} \mathrm{m}^{-3}$ and $60 \pm 19 \mathrm{ng} \mathrm{m}^{-3}$ in $\mathrm{PM}_{2.5}$ and $44 \pm 28 \mathrm{ng} \mathrm{m}^{-3}$ and $78 \pm 45 \mathrm{ng} \mathrm{m}^{-3}$ in $\mathrm{PM}_{10}$ during the wet and dry season, respectively (Table 1). Glyoxylic acid $\left(\omega \mathrm{C}_{2}\right)$, an important precursor of oxalic acid (Warneck, 2003), was the most abundant ketoacid in both seasons and sizes followed by 9oxononoic acid $\left(\omega \mathrm{C}_{9}\right)$. Interestingly, $\omega \mathrm{C}_{9}$ is mostly present in larger size $\left(\mathrm{PM}_{10}\right)$ in both seasons (Table 1), suggesting that the production of $\omega \mathrm{C}_{9}$ via the oxidation of biogenic unsaturated fatty acids (Kawamura and Gagosian, 1987) occurs mainly in aerosol phase. In fact, oleic acid (the precursor unsaturated fatty acid) largely exists in $\mathrm{PM}_{10}$ (Table 1 ). This is in contrast to $\omega \mathrm{C}_{2}$, which is mostly present in $\mathrm{PM}_{2.5}$ (see Table 1) and is mainly produced in gaseous phase. Other studies in China (Ho et al., 2007), India (Pavuluri et al., 2010), Japan (Aggarwal and Kawamura, 2008), Korea (Kundu et al., 2010b), Mongolia (Jung et al., 2010), and polar region (Kawamura et al., 2010, 2012) have reported the predominance of $\omega \mathrm{C}_{2}$ in ketoacids.

Mean concentrations of total $\alpha$-dicarbonyls in $\mathrm{PM}_{2.5}$ were higher in wet season $\left(6.4 \pm 3.0 \mathrm{ng} \mathrm{m}^{-3}\right)$ than dry season $\left(4.4 \pm 1.7 \mathrm{ng} \mathrm{m}^{-3}\right)$ whereas those in $\mathrm{PM}_{10}$ were equivalent $\left(7.3 \pm 1.9 \mathrm{ng} \mathrm{m}^{-3}\right.$ in wet season and $8.0 \pm 3.5 \mathrm{ng} \mathrm{m}^{-3}$ in dry seasons) (Table 1). In both seasons and size fractions, glyoxal (Gly) was found to be more abundant than methylglyoxal (Table 2). Gly may be produced by the photooxidation of anthropogenic hydrocarbons (Ho et al., 2006) and $p$-xylene (Volkamer et al., 2001). In contrast to diacids and ketoacids, lower concentrations of $\alpha$-dicarbonyls in $\mathrm{PM}_{2.5}$ were obtained during the dry season, which may be caused by photochemical degradation under stronger solar radiation in dry season. The aldehyde group in dicarbonyls is highly susceptible for nucleophilic addition of oxygen forming carboxylic acid (Ervens et al., 2004; Fick et al., 2004). Thus, $\alpha$-dicarbonyls may be in part converted to organic acids such as glyoxylic acid and oxalic acid in aerosol phase and the carbonyl concentrations may be decreased in dry season.

Homologous series of straight chain fatty acids $\left(\mathrm{C}_{14: 0^{-}}\right.$ $\left.\mathrm{C}_{24: 0}\right)$ and unsaturated fatty acid $\left(\mathrm{C}_{18: 1}\right)$ were detected (Table 1). Mean concentrations of total fatty acids in $\mathrm{PM}_{2.5}$ were $26 \pm 19 \mathrm{ng} \mathrm{m}^{-3}$ and $32 \pm 15 \mathrm{ng} \mathrm{m}^{-3}$ during the wet and dry seasons, respectively, whereas those in $\mathrm{PM}_{10}$ were $102 \pm 44 \mathrm{ng} \mathrm{m}^{-3}$ and $117 \pm 72 \mathrm{ng} \mathrm{m}^{-3}$. Average molecular compositions of fatty acids and their size distributions in the 
Table 1. Average concentrations and concentration ranges $\left(\mathrm{ng} \mathrm{m}^{-3}\right)$ of diacids, ketoacids, $\alpha$-dicarbonyls and fatty acids in $\mathrm{PM}_{2.5}$ and $\mathrm{PM}_{10}$ during 2011 wet and dry seasons in Morogoro.

\begin{tabular}{|c|c|c|c|c|c|c|c|c|c|c|c|c|c|c|c|c|}
\hline \multirow[t]{3}{*}{ Compounds } & \multicolumn{8}{|c|}{$\mathrm{PM}_{2.5}$} & \multicolumn{8}{|c|}{$\mathrm{PM}_{10}$} \\
\hline & \multicolumn{4}{|c|}{ Wet season } & \multicolumn{4}{|c|}{ Dry season } & \multicolumn{4}{|c|}{ Wet season } & \multicolumn{4}{|c|}{ Dry season } \\
\hline & Min. & Max. & Avg. & S.D & Min. & Max. & Avg. & S.D & Min. & Max. & Avg. & S.D & Min. & Max. & Avg. & S.D \\
\hline \multicolumn{17}{|l|}{ Dicarboxylic acids } \\
\hline \multicolumn{17}{|c|}{ Saturated straight chain diacids } \\
\hline Oxalic, $\mathrm{C}_{2}$ & 47.7 & 221.8 & 121.5 & 46.6 & 170.8 & 392.6 & 258.1 & 69.5 & 114.7 & 248.9 & 168.6 & 42.4 & 140.2 & 659.1 & 292.4 & 164.8 \\
\hline Malonic, $\mathrm{C}_{3}$ & 5.0 & 23.1 & 11.1 & 5.5 & 16.1 & 36.1 & 25.6 & 7.7 & 14.8 & 49.9 & 26.9 & 10.0 & 20.1 & 95.8 & 42.8 & 28.1 \\
\hline Succinic, $\mathrm{C}_{4}$ & 6.8 & 32.0 & 15.1 & 7.0 & 19.1 & 52.1 & 32.4 & 10.4 & 9.9 & 37.3 & 21.3 & 7.5 & 15.4 & 94.4 & 42.9 & 24.8 \\
\hline Glutaric, $\mathrm{C}_{5}$ & 1.0 & 4.5 & 2.4 & 1.2 & 3.0 & 8.4 & 5.4 & 1.8 & 1.3 & 6.8 & 3.0 & 1.6 & 2.7 & 14.7 & 8.2 & 4.1 \\
\hline Adipic, $\mathrm{C}_{6}$ & 2.3 & 6.5 & 4.0 & 1.7 & 9.0 & 35.3 & 18.1 & 7.1 & 1.5 & 4.6 & 2.6 & 1.0 & 2.3 & 25.0 & 6.4 & 5.6 \\
\hline Pimeric, $C_{7}$ & NA & NA & NA & NA & 0.9 & 1.3 & 1.1 & 0.2 & 0.9 & 2.8 & 1.5 & 0.9 & 0.1 & 10.4 & 2.7 & 2.2 \\
\hline Suberic, $\mathrm{C}_{8}$ & 3.3 & 7.7 & 5.9 & 2.3 & NA & NA & NA & NA & NA & NA & NA & NA & NA & NA & NA & NA \\
\hline Azelaic, $\mathrm{C}_{9}$ & 1.5 & 7.3 & 3.5 & 1.9 & 7.4 & 34.2 & 18.0 & 7.2 & 0.7 & 32.2 & 16.3 & 9.5 & 4.4 & 64.1 & 24.2 & 18.4 \\
\hline Total $\mathrm{C}_{2}-\mathrm{C}_{9}$ & 68.5 & 293.3 & 158.9 & 61.8 & 233.7 & 510.9 & 357.8 & 87.3 & 154.0 & 360.7 & 239.4 & 67.2 & 204.3 & 900.4 & 419.6 & 228.6 \\
\hline \multicolumn{17}{|l|}{ Unsaturated diacids } \\
\hline Methylmalonic, $\mathrm{iC}_{4}$ & 0.5 & 4.0 & 1.3 & 1.0 & 0.6 & 1.9 & 0.8 & 0.5 & 0.6 & 29.3 & 3.7 & 1.5 & 0.8 & 2.0 & 1.3 & 0.4 \\
\hline Methylsuccinic, $\mathrm{iC}_{5}$ & 0.9 & 4.2 & 2.4 & 1.1 & 2.0 & 6.1 & 3.4 & 1.3 & 1.3 & 4.9 & 3.0 & 1.1 & 2.0 & 11.5 & 4.3 & 2.9 \\
\hline Maleic, $\mathrm{M}$ & 0.8 & 1.5 & 1.2 & 0.3 & 2.0 & 4.5 & 3.0 & 0.8 & 0.7 & 2.2 & 1.2 & 0.5 & 1.1 & 6.9 & 2.8 & 2.0 \\
\hline Fumaric, F & 1.8 & 5.0 & 3.0 & 1.0 & 1.9 & 5.3 & 3.1 & 1.0 & 1.5 & 4.1 & 2.9 & 1.0 & 2.3 & 7.8 & 4.6 & 1.9 \\
\hline Methylmaleic, mM & 0.5 & 8.3 & 2.2 & 1.4 & 0.6 & 2.2 & 1.2 & 0.5 & 1.2 & 4.3 & 2.4 & 0.9 & 0.7 & 4.4 & 2.1 & 1.4 \\
\hline Phthalic, $\mathrm{Ph}$ & 9.2 & 17.7 & 12.9 & 2.7 & 7.5 & 17.4 & 12.7 & 3.2 & 3.3 & 12.3 & 7.8 & 2.8 & 4.7 & 23.3 & 17.9 & 6.5 \\
\hline Isophthalic, iPh & 0.2 & 3.3 & 1.2 & 1.0 & 0.0 & 0.0 & 0.0 & 0.0 & 0.2 & 7.2 & 3.7 & 2.4 & 0.0 & 0.0 & 0.0 & 0.0 \\
\hline Terephthalic, $\mathrm{tPh}$ & 0.5 & 3.3 & 1.9 & 1.0 & 2.4 & 4.9 & 3.3 & 1.4 & 0.6 & 1.3 & 1.0 & 0.4 & 0.7 & 3.7 & 2.0 & 1.2 \\
\hline Total diacids & 97.2 & 328.7 & 183.2 & 63.9 & 252.2 & 547.5 & 383.3 & 92.6 & 165.5 & 390.8 & 263.4 & 71.6 & 217.7 & 959.5 & 454.7 & 240.6 \\
\hline \multicolumn{17}{|l|}{ Ketocarboxylic acids } \\
\hline Glyoxylic, $\omega \mathrm{C}_{2}$ & 5.6 & 23.1 & 12.1 & 5.0 & 17.8 & 40.8 & 29.7 & 8.7 & 8.9 & 23.7 & 13.8 & 4.3 & 11.1 & 58.7 & 29.3 & 13.3 \\
\hline 3-Oxopropanoic, $\omega \mathrm{C}_{3}$ & 0.4 & 7.7 & 3.7 & 2.1 & 3.2 & 6.7 & 4.9 & 1.2 & 1.2 & 3.1 & 1.8 & 0.6 & 1.1 & 6.0 & 3.5 & 1.5 \\
\hline 4-Oxobutanoic $\omega \mathrm{C}_{4}$ & 0.2 & 2.7 & 0.8 & 1.0 & 0.7 & 4.6 & 2.8 & 1.6 & 0.3 & 3.9 & 1.5 & 1.0 & 1.2 & 17.5 & 5.2 & 3.6 \\
\hline 5-Oxopentanoic, $\omega \mathrm{C}_{5}$ & 0.4 & 1.5 & 1.0 & 0.5 & 1.3 & 1.9 & 1.6 & 0.3 & 0.4 & 0.4 & 0.4 & 0.0 & 1.0 & 3.7 & 2.1 & 1.4 \\
\hline 7-Oxoheptanoic, $\omega \mathrm{C}_{7}$ & 0.5 & 7.3 & 3.0 & 2.3 & 2.8 & 8.1 & 5.4 & 2.1 & 1.5 & 8.0 & 3.6 & 2.0 & 2.1 & 10.7 & 5.9 & 2.6 \\
\hline 8-Oxooctanoic, $\omega \mathrm{C}_{8}$ & 0.6 & 2.9 & 1.5 & 0.9 & 1.1 & 5.1 & 2.9 & 1.4 & 0.3 & 3.8 & 1.3 & 1.1 & 0.7 & 4.4 & 2.6 & 1.2 \\
\hline 9-Oxononoic, $\omega \mathrm{C}_{9}$ & 0.5 & 13.9 & 6.6 & 4.3 & 5.6 & 11.5 & 7.8 & 2.1 & 2.9 & 47.6 & 18.7 & 12.3 & 6.1 & 41.1 & 22.4 & 14.3 \\
\hline Pyruvic, Pyr & 1.4 & 6.8 & 2.7 & 1.7 & 1.7 & 7.5 & 4.4 & 1.9 & 1.9 & 8.0 & 3.4 & 1.8 & 1.3 & 16.6 & 7.4 & 5.0 \\
\hline Total ketocarboxylic acids & 9.6 & 65.9 & 31.4 & 17.8 & 34.3 & 86.1 & 59.6 & 19.3 & 17.4 & 98.4 & 44.4 & 28.0 & 24.7 & 158.7 & 78.3 & 44.9 \\
\hline \multicolumn{17}{|l|}{$\alpha$-Dicarbonyls } \\
\hline Glyoxal, Gly & 2.3 & 13.3 & 5.2 & 3.3 & 2.6 & 7.0 & 4.2 & 1.4 & 4.6 & 9.8 & 6.7 & 1.8 & 3.7 & 13.4 & 7.8 & 3.3 \\
\hline Methylglyoxal, MeGly & 0.01 & 2.8 & 1.4 & 0.9 & 0.2 & 1.0 & 0.5 & 0.3 & 0.3 & 0.9 & 0.6 & 0.2 & 0.1 & 0.8 & 0.4 & 0.3 \\
\hline Total $\alpha$-dicarbonyls & 2.9 & 13.3 & 6.4 & 3.0 & 2.6 & 7.3 & 4.4 & 1.7 & 4.9 & 10.6 & 7.3 & 1.9 & 3.7 & 14.1 & 8.0 & 3.5 \\
\hline \multicolumn{17}{|l|}{ Fatty acids } \\
\hline Myristic, $\mathrm{C}_{14: 0}$ & 1.5 & 18.8 & 9.0 & 5.2 & 12.1 & 22.7 & 17.9 & 3.8 & 6.3 & 15.4 & 9.7 & 3.2 & 4.4 & 35.8 & 17.9 & 8.8 \\
\hline Palmitic, $\mathrm{C}_{16: 0}$ & 3.2 & 34.0 & 13.2 & 10.3 & NA & NA & NA & NA & 17.0 & 51.8 & 32.7 & 10.8 & 4.1 & 66.9 & 25.5 & 20.3 \\
\hline Stearic, $\mathrm{C}_{18: 0}$ & 1.4 & 7.3 & 4.7 & 1.7 & 1.1 & 8.1 & 3.4 & 2.6 & 6.4 & 23.8 & 13.2 & 6.1 & 2.2 & 11.3 & 4.8 & 3.3 \\
\hline Oleic, $\mathrm{C}_{18: 1}$ & 2.1 & 8.0 & 6.0 & 2.3 & 1.7 & 11.4 & 6.4 & 3.8 & 5.8 & 27.3 & 12.7 & 5.6 & 1.7 & 33.4 & 9.2 & 8.0 \\
\hline Arachidic, $\mathrm{C}_{20: 0}$ & NA & NA & NA & NA & 1.1 & 8.1 & 3.4 & 2.6 & 3.3 & 36.5 & 14.6 & 11.5 & 2.2 & 11.3 & 4.8 & 3.3 \\
\hline Behenic, $\mathrm{C}_{22: 0}$ & NA & NA & NA & NA & NA & NA & NA & NA & 1.1 & 26.4 & 12.0 & 9.9 & 9.9 & 30.0 & 18.1 & 5.6 \\
\hline Lignoceric, $\mathrm{C}_{24: 0}$ & NA & NA & NA & NA & NA & NA & NA & NA & 1.5 & 23.8 & 9.3 & 7.5 & 7.0 & 32.3 & 14.2 & 7.1 \\
\hline Total fatty acids & 4.4 & 66.0 & 26.1 & 19.3 & 12.1 & 52.5 & 31.9 & 15.4 & 48.7 & 197.4 & 102.0 & 43.8 & 46.7 & 273.7 & 117.2 & 72.4 \\
\hline
\end{tabular}

NA = Not Available

wet and dry seasons are shown in Figs. 2 and 3, respectively. Fatty acids with even carbon-number predominance were detected with a peak at myristic acid $\left(\mathrm{C}_{14: 0}\right)$ in $\mathrm{PM}_{2.5}$ and palmitic acid $\left(\mathrm{C}_{16: 0}\right)$ in $\mathrm{PM}_{10}$ in both seasons, indicating a significant emission of lipid class compounds from biological sources (Lechevalier, 1977; Simoneit, 1988). Palmitic $\left(\mathrm{C}_{16: 0}\right)$ and stearic $\left(\mathrm{C}_{18: 0}\right)$ acids showed higher concentrations in wet season in both sizes probably due to enhanced emissions from vegetation sources. In contrast, longer-chain fatty acids, behenic $\left(\mathrm{C}_{22}\right)$ and lignoceric $\left(\mathrm{C}_{24}\right)$, which are specific to terrestrial higher plants (Kawamura et al., 2003), were not detected in $\mathrm{PM}_{2.5}$, but were abundantly detected in $\mathrm{PM}_{10}$. They showed higher concentrations during the dry season, suggesting a long-range atmospheric transport of lipid compounds.

Higher concentration of azelaic acid $\left(\mathrm{C}_{9}\right)$ and higher ratios of $\mathrm{C}_{9}$ to oleic acid $\left(\mathrm{C}_{18: 1}\right)$ were found in the dry season for both sizes. Mean $\mathrm{C}_{9} / \mathrm{C}_{18: 1}$ ratios in $\mathrm{PM}_{2.5}$ were higher in dry season (4.5) than wet season (0.63). Similar trend was observed in $\mathrm{PM}_{10}$ : 8.6 (dry season) and 1.5 (wet season). 


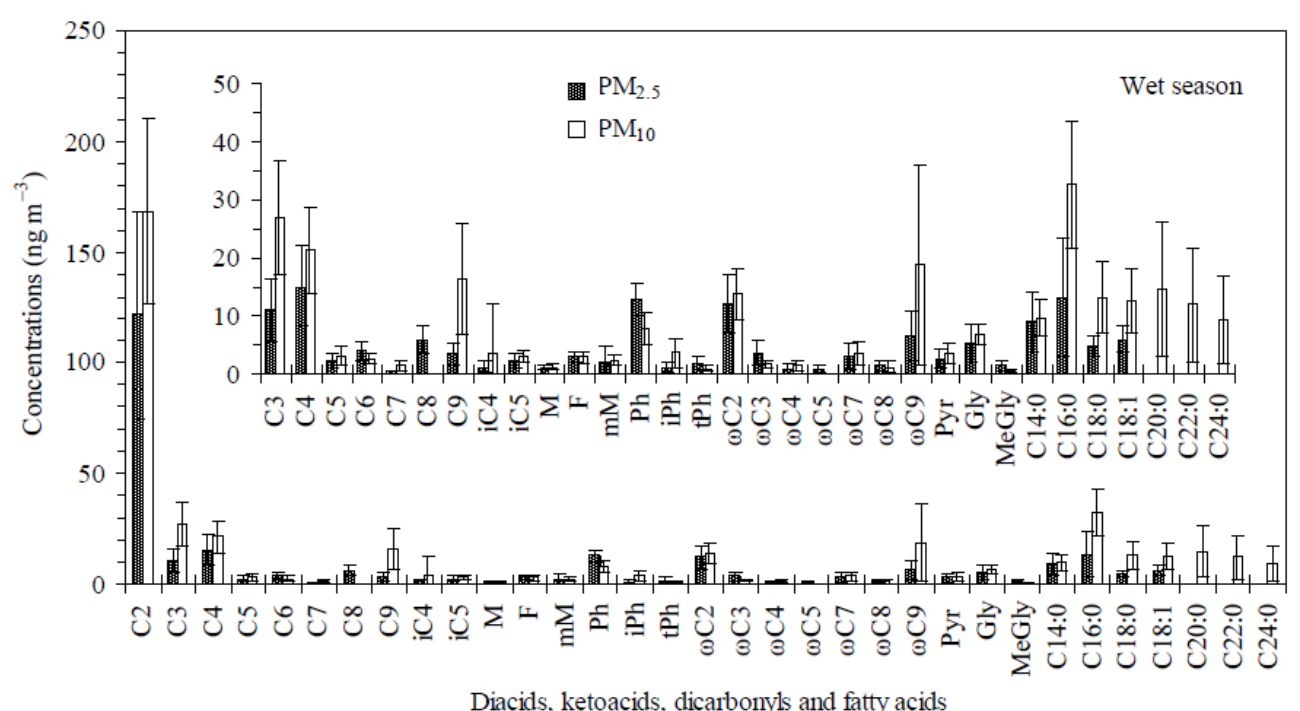

Fig. 2. Average molecular compositions of diacids, ketoacids, $\alpha$-dicarbonyls and fatty acids in $\mathrm{PM}_{2.5}$ and $\mathrm{PM}_{10}$ from Morogoro during 2011 wet season. See Table 1 for abbreviations.

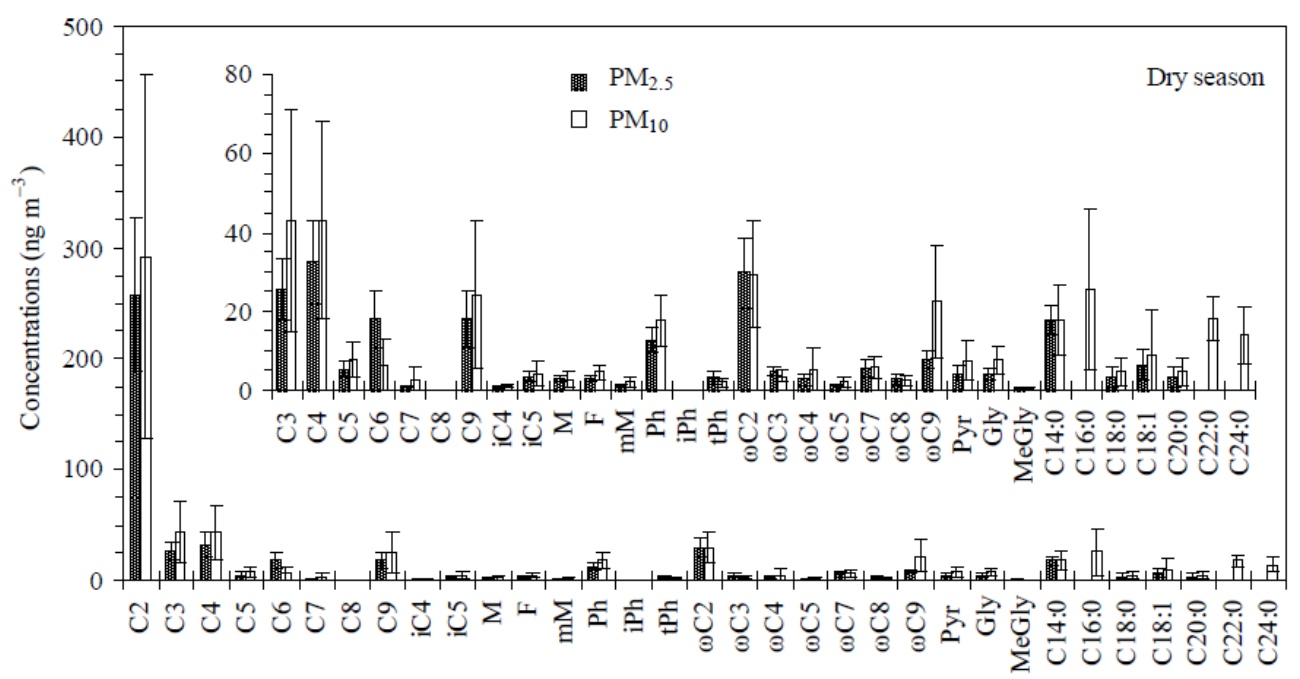

Diacids, ketoacids, dicarbonyls and fatty acids

Fig. 3. Average molecular compositions of diacids, ketoacids, $\alpha$-dicarbonyls and fatty acids in $\mathrm{PM}_{2.5}$ and $\mathrm{PM}_{10}$ from Morogoro during 2011 dry season. See Table 1 for abbreviations.

Photochemical oxidation of $\mathrm{C}_{18: 1}$ to $\mathrm{C}_{9}$ via ozone and/or $\mathrm{OH}$ radicals (directly or via its intermediate precursor $\omega \mathrm{C}_{9}$ ) is likely in the atmosphere during the long-range transport (Kawamura and Gagosian, 1987; Stephanou and Stratigakis, 1993). The highest $C_{9} / C_{18: 1}$ ratio in the dry season for $\mathrm{PM}_{2.5}$ and $\mathrm{PM}_{10}$ may be due to an enhanced photochemical degradation of $\mathrm{C}_{18: 1}$. On other hand, mean $\mathrm{C}_{18: 1} / \mathrm{C}_{18: 0}$ ratios in $\mathrm{PM}_{2.5}$ were 1.2 and 1.9 in the wet and dry seasons, respectively whereas those in $\mathrm{PM}_{10}$ were 1.1 and 1.6, respectively. The lower mean $\mathrm{C}_{18: 1} / \mathrm{C}_{18: 0}$ ratios in the wet season compared to dry season in both sizes may suggest that photo- chemical degradation of $\mathrm{C}_{18: 1}$ may be accelerated in aqueous aerosols under wet conditions.

\subsection{Temporal variations of diacids and related compounds}

Figure 5a-e show temporal variations of total aerosol mass, diacids, ketoacids, $\alpha$-dicarbonyls and fatty acids in $\mathrm{PM}_{2.5}$ and $\mathrm{PM}_{10}$ during the wet and dry seasons. Temporal variations of selected diacids $\left(\mathrm{C}_{2}-\mathrm{C}_{9}\right)$ are given in Fig. 6. Concentrations of $\mathrm{C}_{2}, \mathrm{C}_{3}$ and $\mathrm{C}_{4}$ diacids showed similar temporal variations with higher concentrations during dry season compared to wet season in both sizes (Fig. 6a-c), suggesting 
(a) $\mathrm{PM}_{2.5}$ wet season

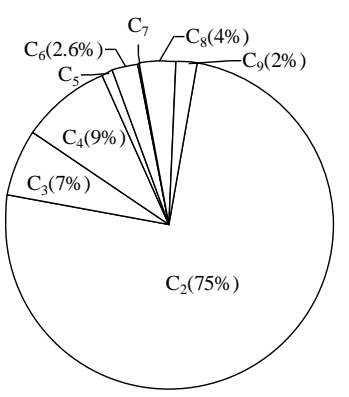

(c) $\mathrm{PM}_{10}$ wet season

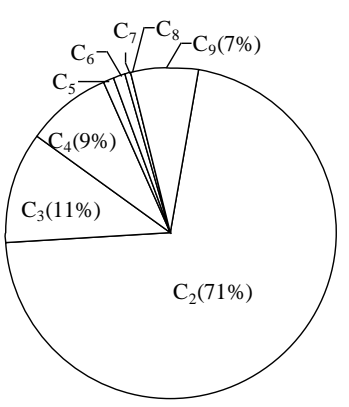

(b) $\mathrm{PM}_{2.5}$ dry season

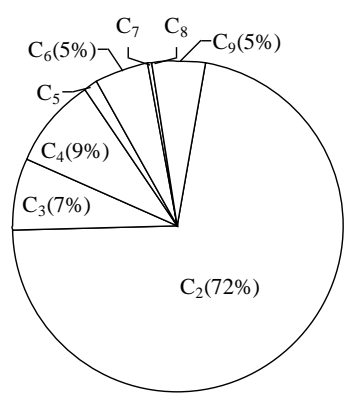

(d) $\mathrm{PM}_{10}$ dry season

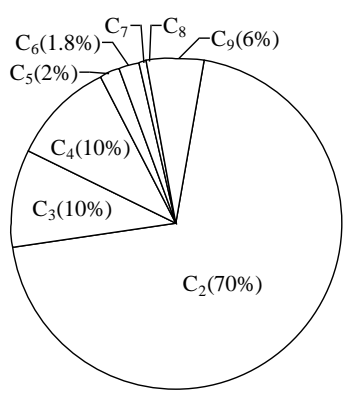

Fig. 4. The relative abundances $(\%)$ of individual diacids in total straight-chain diacids $\left(\mathrm{C}_{2}-\mathrm{C}_{9}\right)$ in $\mathrm{PM}_{2.5}$ and $\mathrm{PM}_{10}$ collected in wet $(\mathbf{a}, \mathbf{c})$ and dry $(\mathbf{b}, \mathbf{d})$ seasons in Morogoro.

more production and/or accumulation of the diacids in dry season. The $\mathrm{C}_{2} /$ total diacids ratios in $\mathrm{PM}_{2.5}$ were $0.65 \pm 0.06$ (range: $0.49-0.72$ ) in wet season and $0.67 \pm 0.04$ (range: $0.59-0.72)$ in dry season whereas those in $\mathrm{PM}_{10}$ were $0.65 \pm 0.05$ (range: $0.59-0.76$ ) in wet season and $0.64 \pm 0.04$ (range: $0.54-0.69$ ) in dry season.

\section{3 $\mathrm{PM}_{2.5}$ to $\mathrm{PM}_{10}$ ratios}

Mean $\mathrm{PM}_{2.5} / \mathrm{PM}_{10}$ ratios for total diacids, ketoacids, $\alpha$ dicarbonyls and fatty acids in aerosol samples are shown in Fig. 7 for the wet and dry seasons. The ratios were calculated on the basis of the data for $\mathrm{PM}_{2.5}$ and $\mathrm{PM}_{10}$ samples taken in parallel and averaged overall samples from the campaign. The results indicate that total diacids, ketoacids and $\alpha$-dicarbonyls were mostly present in $\mathrm{PM}_{2.5}$ in both seasons (except for $\alpha$-dicarbonyls in the dry season). This suggests a larger contribution of pyrogenically and photochemically produced organic acids and related compounds, which are most likely enriched in $\mathrm{PM}_{2.5}$ particles. Strong correlation was found between $\mathrm{Ca}^{2+}$ (crustal tracer) with the $\mathrm{PM}_{10}$ mass $\left(r^{2}=0.81\right)$ and with $\alpha$-dicarbonyls $\left(r^{2}=0.33\right)$ in the dry season (in contrast $r^{2}=0.17$ and $r^{2}=0.08$ in the wet season, respectively). Mean $\mathrm{PM}_{2.5}$ to $\mathrm{PM}_{10}$ ratios for total diacids and related compound are larger than $60 \%$ and larger ratios above $80 \%$ were obtained for total diacids and total ketoacids in the dry season and total $\alpha$-dicarbonyls in the wet season (Fig. 7). Other studies have reported associ-

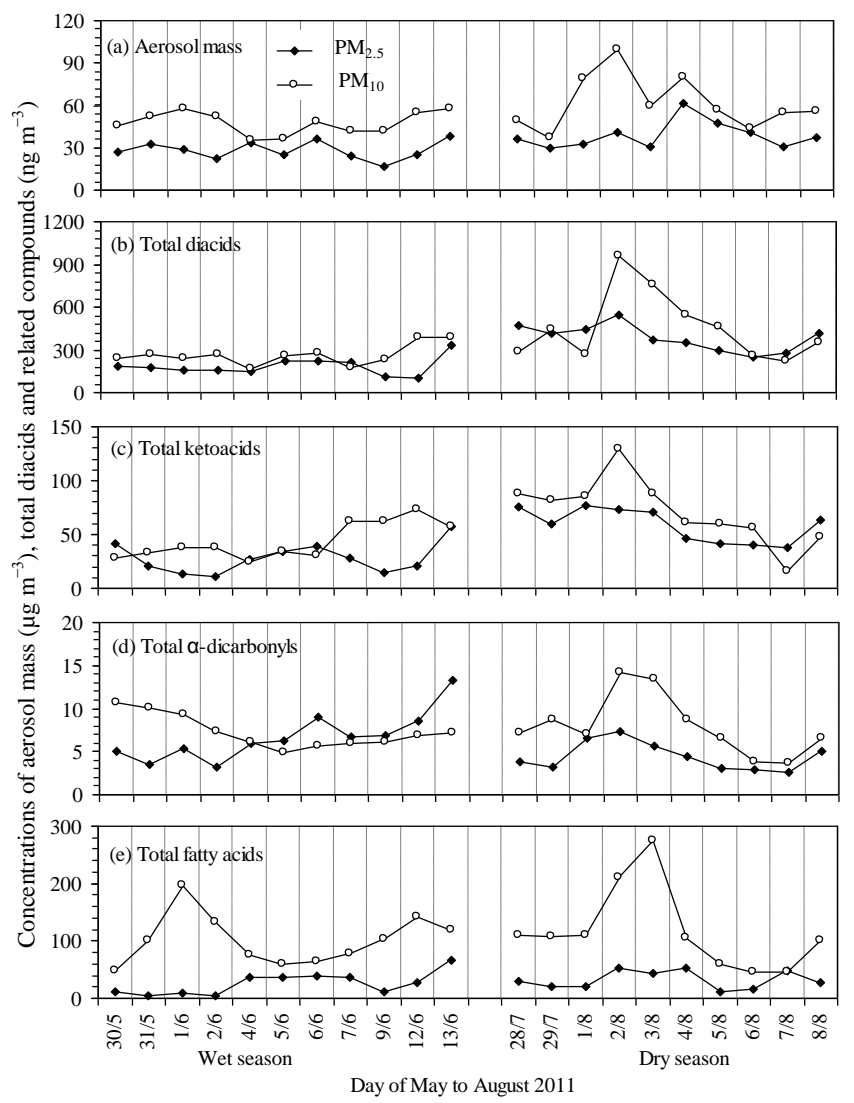

Fig. 5. Temporal variations of the concentrations of (a) aerosol mass, (b) total diacids, (c) total ketoacids, (d) total $\alpha$-dicarbonyls, and (e) total fatty acids in $\mathrm{PM}_{2.5}$ and $\mathrm{PM}_{10}$ during 2011 wet and dry seasons.

ation of diacids and related compounds with fine particles (Narukawa et al., 2003; Kawamura et al., 2007; Wang et al., 2012). Interestingly $\alpha$-dicarbonyls showed a significantly high $\mathrm{PM}_{2.5} / \mathrm{PM}_{10}$ ratio (ca. $85 \%$ ) in wet season. Because glyoxal and methylglyoxal that are mostly present as gas in the atmosphere can form hydrated forms in the presence of moisture, it is reasonable that $\alpha$-dicarbonyls are detected as $\mathrm{PM}_{2.5}$ particles during wet season.

In contrast, fatty acids were found mostly in $\mathrm{PM}_{10}$ in both seasons (Fig. 7). Because fatty acids with carbon number $>14$, in particular $\mathrm{C}_{16}$, are known to be mostly in particulate phase (Cheng et al., 2004), they are likely associated with $\mathrm{PM}_{10}$. This result suggests that fatty acids at our site are from mixed sources (Alfarra et al., 2004), which are derived from primary sources such as viable microbiota in the ambient particles, marine biological activity and/or terrestrial higher plants. Fatty acids in ambient aerosols from rural, urban and oceanic regions have been reported to show the predominance of $\mathrm{C}_{16}$ acid (Simoneit et al., 1988; Limbeck and Puxbaum, 1999; Cheng et al., 2004). 
Table 2. Relative abundances (\%) of individual compound in total diacids, ketoacids, and $\alpha$-dicarbonyls in $\mathrm{PM}_{2.5}$ and $\mathrm{PM}_{10}$ during wet and dry seasons in Morogoro.

\begin{tabular}{|c|c|c|c|c|c|c|c|c|c|c|c|c|}
\hline \multirow[t]{3}{*}{ Compounds } & \multicolumn{6}{|c|}{$\mathrm{PM}_{2.5}$} & \multicolumn{6}{|c|}{$\mathrm{PM}_{10}$} \\
\hline & \multicolumn{3}{|c|}{ Wet season } & \multicolumn{3}{|c|}{ Dry season } & \multicolumn{3}{|c|}{ Wet season } & \multicolumn{3}{|c|}{ Dry season } \\
\hline & Min. & Max. & Avg. & Min. & Max. & Avg. & Min. & Max. & Avg. & Min. & Max. & Avg. \\
\hline \multicolumn{13}{|l|}{ Diacids } \\
\hline Oxalic, $\mathrm{C}_{2}$ & 49.0 & 72.1 & 65.4 & 59.4 & 71.7 & 67.1 & 59.3 & 76.0 & 64.6 & 54.1 & 68.7 & 63.9 \\
\hline Malonic, $\mathrm{C}_{3}$ & 3.5 & 7.0 & 5.8 & 5.4 & 8.7 & 6.6 & 7.8 & 12.9 & 10.1 & 7.3 & 12.1 & 9.1 \\
\hline Succinic, $\mathrm{C}_{4}$ & 6.3 & 9.7 & 8.1 & 6.8 & 9.8 & 8.3 & 6.0 & 9.6 & 8.0 & 7.1 & 10.5 & 9.2 \\
\hline Glutaric, $\mathrm{C}_{5}$ & 0.9 & 1.8 & 1.3 & 1.1 & 1.9 & 1.4 & 0.6 & 1.7 & 1.1 & 1.1 & 3.5 & 1.9 \\
\hline Adipic, $\mathrm{C}_{6}$ & 1.1 & 3.7 & 2.2 & 2.6 & 8.5 & 4.8 & 0.6 & 1.2 & 1.0 & 0.4 & 7.1 & 1.7 \\
\hline Pimeric, $\mathrm{C}_{7}$ & NA & NA & NA & 0.19 & 0.32 & 0.25 & 0.23 & 1.23 & 0.55 & 0.06 & 2.33 & 0.81 \\
\hline Suberic, $\mathrm{C}_{8}$ & 1.5 & 4.4 & 3.4 & NA & NA & NA & NA & NA & NA & NA & NA & NA \\
\hline Azelaic, $\mathrm{C}_{9}$ & 1.0 & 3.2 & 1.9 & 2.5 & 9.8 & 4.9 & 0.4 & 11.9 & 6.0 & 1.6 & 11.8 & 5.1 \\
\hline Methylmalonic, $\mathrm{iC}_{4}$ & 0.3 & 1.3 & 0.7 & 0.15 & 0.54 & 0.24 & 0.3 & 11.2 & 1.4 & 0.2 & 0.7 & 0.3 \\
\hline Methylsuccinic, $\mathrm{iC}_{5}$ & 0.8 & 1.9 & 1.3 & 0.6 & 1.3 & 0.9 & 0.8 & 1.8 & 1.2 & 0.7 & 1.2 & 0.9 \\
\hline Maleic, $\mathrm{M}$ & 0.4 & 1.2 & 0.7 & 0.4 & 1.6 & 0.8 & 0.31 & 0.83 & 0.48 & 0.37 & 0.78 & 0.58 \\
\hline Fumaric, F & 0.8 & 3.8 & 1.8 & 0.5 & 1.4 & 0.8 & 0.6 & 1.7 & 1.1 & 0.8 & 1.2 & 1.1 \\
\hline Methylmaleic, mM & 0.4 & 5.3 & 1.3 & 0.16 & 0.52 & 0.31 & 0.4 & 1.6 & 0.9 & 0.24 & 0.77 & 0.44 \\
\hline Phthalic, $\mathrm{Ph}$ & 5.0 & 18.2 & 8.0 & 2.4 & 4.0 & 3.3 & 1.9 & 5.1 & 3.0 & 2.2 & 8.0 & 4.5 \\
\hline Isophthalic, $\mathrm{iPh}$ & 0.2 & 1.3 & 0.7 & NA & NA & NA & 0.1 & 2.4 & 1.4 & NA & NA & NA \\
\hline Terephthalic, $\mathrm{tPh}$ & 0.2 & 2.6 & 1.4 & 0.52 & 0.90 & 0.71 & 0.27 & 0.33 & 0.29 & 0.20 & 0.67 & 0.44 \\
\hline \multicolumn{13}{|l|}{ Ketoacids } \\
\hline Glyoxylic, $\omega \mathrm{C}_{2}$ & 30.9 & 83.2 & 46.9 & 38.2 & 56.4 & 50.7 & 14.4 & 47.2 & 34.4 & 29.0 & 67.9 & 43.4 \\
\hline 3-Oxopropanoic, $\omega \mathrm{C}_{3}$ & 4.0 & 18.9 & 12.0 & 5.4 & 10.5 & 8.5 & 2.0 & 6.5 & 4.7 & 3.5 & 7.0 & 5.0 \\
\hline 4-Oxobutanoic $\omega \mathrm{C}_{4}$ & 0.9 & 4.7 & 2.2 & 1.9 & 8.9 & 4.7 & 0.5 & 7.5 & 3.8 & 1.4 & 21.5 & 6.1 \\
\hline 5-Oxopentanoic, $\omega \mathrm{C}_{5}$ & 1.0 & 4.4 & 2.4 & 1.8 & 3.8 & 2.5 & NA & NA & NA & 1.2 & 2.9 & 2.0 \\
\hline 7-Oxoheptanoic, $\omega \mathrm{C}_{7}$ & 2.5 & 14.6 & 9.2 & 7.2 & 12.4 & 9.0 & 2.5 & 14.1 & 8.8 & 6.1 & 12.8 & 8.5 \\
\hline 8-Oxooctanoic, $\omega \mathrm{C}_{8}$ & 3.0 & 6.2 & 4.8 & 2.8 & 7.3 & 4.7 & 0.4 & 6.7 & 3.0 & 2.2 & 6.0 & 3.8 \\
\hline 9-Oxononoic, $\omega \mathrm{C}_{9}$ & 1.7 & 40.2 & 23.9 & 7.7 & 18.0 & 13.8 & 8.6 & 76.8 & 37.3 & 9.1 & 48.5 & 28.0 \\
\hline Pyruvic & 5.3 & 18.2 & 9.4 & 4.2 & 14.7 & 7.6 & 3.1 & 23.9 & 8.8 & 4.7 & 30.8 & 11.4 \\
\hline \multicolumn{13}{|l|}{$\alpha$-Dicarbonyls } \\
\hline Glyoxal, Gly & 61.0 & 100.0 & 79.5 & 85.2 & 100.0 & 95.0 & 88.0 & 94.1 & 92.0 & 93.1 & 100.0 & 98.2 \\
\hline Methylglyoxal, MeGly & 0.2 & 39.0 & 25.0 & 3.0 & 14.8 & 10.0 & 5.9 & 12.0 & 8.0 & 1.1 & 6.9 & 3.7 \\
\hline
\end{tabular}

NA $=$ Not Available

\subsection{Seasonal contributions of diacids, ketoacids, and $\alpha$-dicarbonyls to the PM mass, TC, and WSOC}

Temporal variations in the contributions of total diacids to the aerosol mass, total carbon (TC), and water-soluble organic carbon (WSOC) in $\mathrm{PM}_{2.5}$ and $\mathrm{PM}_{10}$ during the wet and dry seasons are given in Fig. 8a-c. We generally found that the mean ratios are higher in the dry season than in the wet season for both size fractions. The mean contributions of total diacids to $\mathrm{PM}_{2.5}$ mass were $0.65 \%$ (range: $0.38-0.89 \%$ ) in the wet season and $1.04 \%$ (range: $0.57-1.39 \%$ ) in the dry season whereas those to $\mathrm{PM}_{10}$ mass were $0.97 \%$ (range: $0.50-1.52 \%$ ) in the wet season and $1.20 \%$ (range: 0.59 $2.47 \%$ ) in the dry season. Total diacid-C/TC ratios ranged from 0.73 to $5.0 \%$ (mean: $2.4 \pm 0.70 \%$ ) in $\mathrm{PM}_{2.5}$ and 1.3 to $3.2 \%$ (mean: $3.0 \pm 1.4 \%$ ) in $\mathrm{PM}_{10}$. The averaged ratios of $1.4 \%$ in $\mathrm{PM}_{2.5}$ and $2.1 \%$ in $\mathrm{PM}_{10}$ in the wet season are twice lower than $3.3 \%$ in $\mathrm{PM}_{2.5}$ and $3.9 \%$ in $\mathrm{PM}_{10}$ in the dry season (Fig. 8b). The higher ratios (e.g., diacid-C/TC) in $\mathrm{PM}_{10}$ than in $\mathrm{PM}_{2.5}$ may suggest that diacids are more enriched in coarse fraction due to the heterogeneous production on the coarse aerosol particles.

The mean contributions of total diacids to TC at our site (2.4\% in $\mathrm{PM}_{2.5}$ and $3.0 \%$ in $\mathrm{PM}_{10}$ ) are much higher than those reported in Sapporo (1.8\%) (Aggarwal and Kawamura, 2008) and in Tokyo (0.95\%) (Kawamura and Ikushima, 1993), in Chennai, India (1.6\%) (Pavuluri et al., 2010) and in Mongolia (0.60\%) (Jung et al., 2010). These comparisons may suggest that photochemical production of diacids is more significant in tropical Tanzania than in mid latitudes 


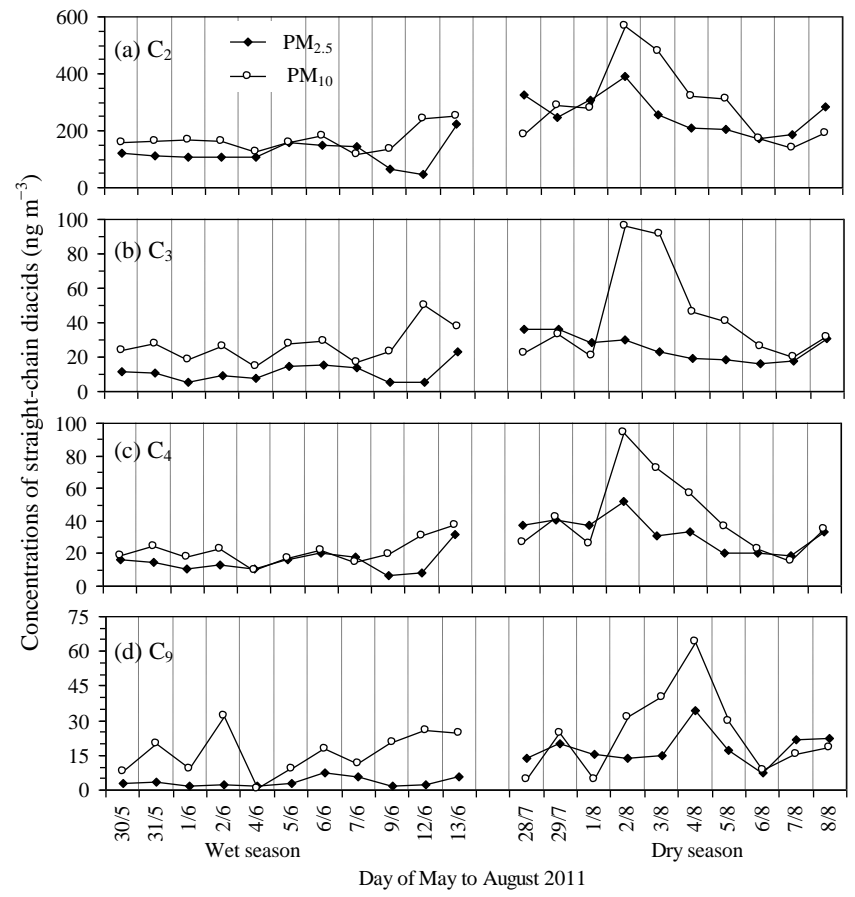

Fig. 6. Temporal variations of the concentrations of (a) oxalic acid $\left(\mathrm{C}_{2}\right)$, (b) malonic acid $\left(\mathrm{C}_{3}\right)$, (c) succinic acid $\left(\mathrm{C}_{4}\right)$, (d) azelaic acid $\left(\mathrm{C}_{9}\right)$ and in $\mathrm{PM}_{2.5}$ and $\mathrm{PM}_{10}$ during 2011 wet and dry seasons.

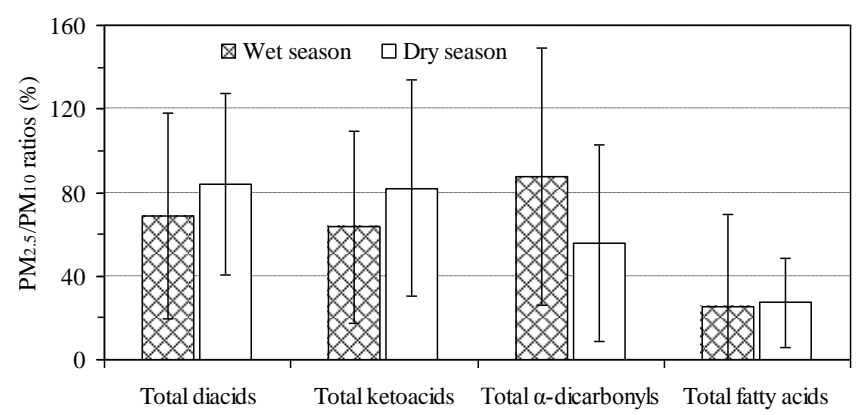

Fig. 7. Mean concentration ratios (\%) of total diacids, ketoacids and $\alpha$-dicarbonyls in $\mathrm{PM}_{2.5}$ to those in $\mathrm{PM}_{10}$ during the 2011 wet and dry season campaigns in Morogoro.

via gas-to-particle conversion of precursor organics as well as heterogeneous reactions on aerosols under the conditions of stronger solar radiation and higher humidity. However, the ratios at our site are lower than that $(8.8 \%)$ reported in remote marine aerosols including the tropical Pacific (Kawamura and Sakaguchi, 1999), where photochemical processes are more enhanced during long-range atmospheric transport.

Contributions of total diacids to WSOC in $\mathrm{PM}_{2.5}$ during the wet and dry seasons were $2.2 \%$ (range: $1.1-3.0 \%$ ) and $4.7 \%$ (range: $2.1-6.9 \%$ ), respectively, whereas those in $\mathrm{PM}_{10}$ were $3.1 \%$ (range: $2.0-5.8 \%$ ) during the wet season and $5.8 \%$ (range: $2.7-14.3 \%$ ) during the dry season. Higher ratios in the dry season further support enhanced pho-

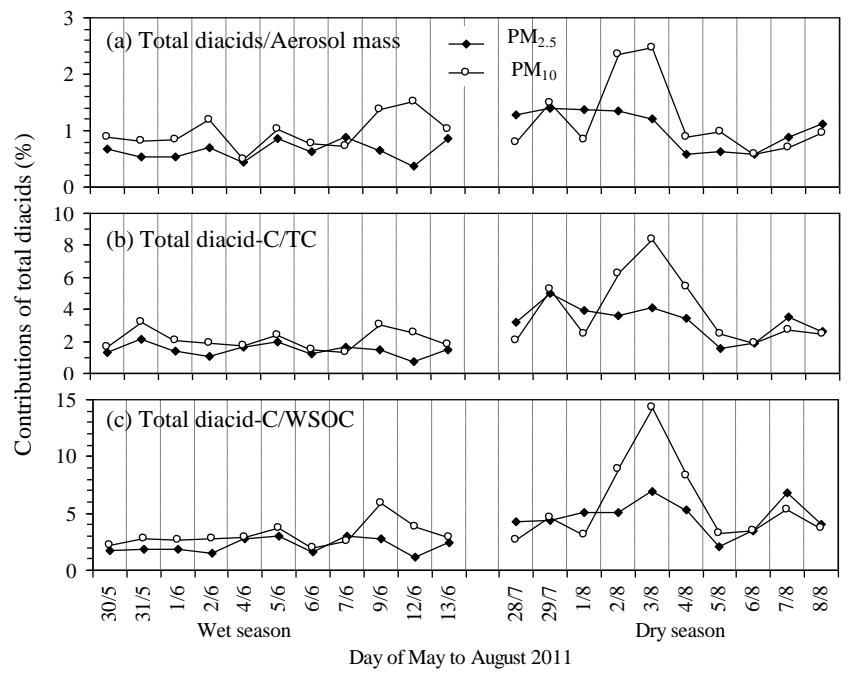

Fig. 8. Temporal variations in contributions (\%) of total diacids to (a) aerosol mass, (b) total carbon (TC), and (c) water-soluble organic carbon (WSOC) in $\mathrm{PM}_{2.5}$ and $\mathrm{PM}_{10}$ during 2011 wet and dry seasons.

tochemical oxidations of organic precursors and production of water-soluble diacids in the dry season. In fact the contributions of total diacids to WSOC in the dry season were 2 times higher than those for wet season in both sizes; $6.5 \%$ and $14.4 \%$ in $\mathrm{PM}_{2.5}$ and $9.3 \%$ and $17.4 \%$ in $\mathrm{PM}_{10}$ for wet and dry seasons, respectively. These results again demonstrate that photochemical production of diacids is more significant in dry season than wet season.

On the other hand, mean contributions of total ketoacids to TC in the wet and dry season were $0.29 \%$ and $0.65 \%$ in $\mathrm{PM}_{2.5}$ and $0.54 \%$ and $0.81 \%$ in $\mathrm{PM}_{10}$, respectively. Their contributions to WSOC were $0.43 \%$ and $0.95 \%$ in $\mathrm{PM}_{2.5}$ and $0.86 \%$ and $1.15 \%$ in $\mathrm{PM}_{10}$, respectively. These results are consistent with the trend obtained for diacids as described above. Higher contributions of total ketoacids to TC and WSOC in the dry season suggest an enhanced photochemical production of organic acids and photochemical aging of organic aerosols in rural Tanzania under higher solar radiation condition. In contrast, total $\alpha$-dicarbonyls show similar contributions to TC $\left(0.06 \%\right.$ and $0.05 \%$ in $\mathrm{PM}_{2.5}$ and $0.08 \%$ and $0.09 \%$ in $\left.\mathrm{PM}_{10}\right)$ and to WSOC $(0.09 \%$ and $0.07 \%$ in $\mathrm{PM}_{2.5}$ and $0.11 \%$ and $0.13 \%$ in $\mathrm{PM}_{10}$ ) during both seasons.

\subsection{Comparison of molecular composition of diacids and related compounds with other studies}

Table 3 compares mean concentrations of diacids, ketoacids, and $\alpha$-dicarbonyls in Tanzania with those reported from other sites in Africa, Asia and Europe. Concentrations of total diacids in Morogoro (289-362 $\mathrm{ng} \mathrm{m}^{-3}$ ) are lower than those reported from Sapporo (390 $\mathrm{ng} \mathrm{m}^{-3}$ ), Tokyo (446 $\mathrm{n} \mathrm{m}^{-3}$ ), Chennai (588 $\left.\mathrm{ng} \mathrm{m}^{-3}\right)$, Hong Kong $\left(671 \mathrm{ng} \mathrm{m}^{-3}\right)$ and Jeju Island $\left(648 \mathrm{ng} \mathrm{m}^{-3}\right)$ but comparable to that $\left(359 \mathrm{ng} \mathrm{m}^{-3}\right)$ from 
Table 3. Comparison between average concentrations of diacids, ketoacids, and $\alpha$-dicarbonyls in atmospheric aerosols from Morogoro, Tanzania and different sites around the world.

\begin{tabular}{|c|c|c|c|c|c|c|c|c|c|c|}
\hline \multirow[t]{2}{*}{ Compounds } & \multicolumn{2}{|c|}{${ }^{\mathrm{a}}$ Morogoro, Tanzania } & \multirow{2}{*}{$\begin{array}{l}\begin{array}{l}\text { b Nylsvley, } \\
\text { South Africa }\end{array} \\
\text { TSP, dry }\end{array}$} & \multirow{2}{*}{$\begin{array}{l}{ }^{\mathrm{c}} \text { Sapporo, } \\
\text { Japan }\end{array}$} & \multirow{2}{*}{$\begin{array}{l}\begin{array}{l}\mathrm{d}_{\text {Tokyo, }} \\
\text { Japan }\end{array} \\
\begin{array}{l}\text { TSP, } \\
\text { one year }\end{array}\end{array}$} & \multirow{2}{*}{$\begin{array}{l}\text { e Salzburg, } \\
\text { Austria } \\
\begin{array}{l}\text { TSP, } \\
\text { summer }\end{array}\end{array}$} & \multirow{2}{*}{$\begin{array}{l}{ }^{\mathrm{f}} \text { Chennai, } \\
\text { India } \\
\mathrm{PM}_{10} \text {, winter } \\
\text { and summer }\end{array}$} & \multirow{2}{*}{$\begin{array}{l}\mathrm{g}_{\text {Nainital, }} \\
\text { India } \\
\begin{array}{l}\text { TSP, winter } \\
\text { and summer }\end{array}\end{array}$} & \multirow{2}{*}{$\begin{array}{l}\mathrm{h}_{\text {Hong Kong, }} \\
\text { China } \\
\begin{array}{l}\text { TSP, spring } \\
\text { and summer }\end{array}\end{array}$} & \multirow{2}{*}{$\begin{array}{l}\begin{array}{l}{ }^{\mathrm{i}} \text { Jeju Island, } \\
\text { Korea }\end{array} \\
\begin{array}{l}\text { TSP, } \\
\text { one year }\end{array}\end{array}$} \\
\hline & $\begin{array}{l}\mathrm{PM}_{2.5} \text {, wet } \\
\text { and dry }\end{array}$ & $\begin{array}{l}\mathrm{PM}_{10} \text {, wet } \\
\text { and dry }\end{array}$ & & & & & & & & \\
\hline \multicolumn{11}{|l|}{ Diacids } \\
\hline Oxalic, $\mathrm{C}_{2}$ & 189.8 & 230.5 & 79.2 & 192 & 270 & 15.3 & 360 & 284 & 373 & 473 \\
\hline Malonic, $\mathrm{C}_{3}$ & 18.4 & 34.9 & 51.7 & 77 & 55 & 22 & 52 & 23.2 & 68.4 & 67 \\
\hline Succinic, $\mathrm{C}_{4}$ & 23.8 & 32.1 & 13.1 & 58 & 37 & 14 & 39 & 26 & 52.5 & 52 \\
\hline Glutaric, $\mathrm{C}_{5}$ & 3.9 & 5.5 & 1.9 & 13 & 11 & 2.7 & 10 & 5.7 & 13.5 & 11 \\
\hline Adipic, $\mathrm{C}_{6}$ & 11.1 & 4.5 & 2.6 & 5.1 & 16 & 4.4 & 7.2 & 6.6 & 11.7 & 8.4 \\
\hline Pimeric, $\mathrm{C}_{7}$ & 0.8 & 2.1 & 1.3 & 2.6 & 5.3 & - & 5.2 & 2.2 & 2.3 & 2.6 \\
\hline Suberic, $C_{8}$ & 3.0 & - & 1.8 & 1.1 & 8.4 & - & 8.2 & 0.6 & 2.3 & 2.6 \\
\hline Azelaic, $\mathrm{C}_{9}$ & 10.8 & 20.3 & 5.0 & 6.5 & 23 & - & 21 & 9.8 & 12.9 & 4.7 \\
\hline Methylmalonic, $\mathrm{iC}_{4}$ & 1.1 & 2.5 & - & 1.6 & 2.5 & - & 1.4 & 1.1 & 3.2 & 1.1 \\
\hline Methylsuccinic, $\mathrm{iC}_{5}$ & 2.9 & 3.7 & - & 3.9 & 5.1 & - & 3.8 & 2.6 & 7.2 & - \\
\hline Maleic, M & 2.1 & 2.0 & - & 4.1 & 5.6 & - & 2.1 & 2.3 & 16.2 & 4.9 \\
\hline Fumaric, F & 3.1 & 3.8 & - & 2.1 & 3.7 & - & 1.3 & 2.3 & 3.3 & 5.2 \\
\hline Methylmaleic, $\mathrm{mM}$ & 1.7 & 2.3 & - & 2.8 & 3.8 & - & 2.1 & 1.9 & 6.5 & 5.3 \\
\hline Phthalic, $\mathrm{Ph}$ & 12.8 & 12.9 & 1.5 & 17 & & 3.3 & 21 & 4.7 & 83.9 & 9.8 \\
\hline Isophthalic, $\mathrm{iPh}$ & 1.2 & 3.7 & - & 0.7 & & - & 1.7 & 2.5 & 14.1 & \\
\hline Terephthalic, $\mathrm{tPh}$ & 2.6 & 1.5 & - & 2.6 & & - & 52 & 4.3 & - & - \\
\hline Subtotal & 289 & 362 & 158.1 & 390 & 446 & 61.7 & 588 & 359 & 671 & 648 \\
\hline \multicolumn{11}{|l|}{ Ketoacids } \\
\hline Glyoxylic, $\omega \mathrm{C}_{2}$ & 20.9 & 21.6 & - & 22 & 39 & - & 32 & 15.8 & 30.9 & 36 \\
\hline 3-Oxopropanoic, $\omega \mathrm{C}_{3}$ & 4.3 & 2.7 & - & 0.46 & 3.0 & - & 3.8 & 3.3 & 0.66 & 1.7 \\
\hline 4-Oxobutanoic $\omega \mathrm{C}_{4}$ & 1.8 & 3.4 & - & 0.97 & 3.6 & - & 5.7 & 4.0 & 3.0 & 2.5 \\
\hline 9-Oxononoic, $\omega \mathrm{C}_{9}$ & 7.2 & 20.6 & - & 2.1 & 2.3 & - & 2.1 & 10.5 & 2.6 & 1.4 \\
\hline Pyruvic, Pyr & 3.6 & 5.4 & 5.6 & 9.6 & 6.7 & 2.6 & 6.8 & 5.9 & 2.4 & 13 \\
\hline Subtotal & 37.8 & 53.7 & 5.6 & 35.1 & 54.6 & 2.6 & 50.4 & 39.5 & 39.6 & 54.6 \\
\hline \multicolumn{11}{|l|}{$\alpha$-Dicarbonyls } \\
\hline Glyoxal, Gly & 4.7 & 7.3 & 10.8 & 4.6 & 12 & 9.6 & 4.6 & 6.1 & 2.7 & 0.5 \\
\hline $\begin{array}{l}\text { Methylglyoxal, } \\
\text { MeGly }\end{array}$ & 1.0 & 0.5 & - & 5.1 & 21 & - & 5.5 & 2.5 & 8.2 & 11 \\
\hline Subtotal & 5.7 & 7.8 & 10.8 & 9.7 & 33 & 9.6 & 10.1 & 8.6 & 10.9 & 11.5 \\
\hline
\end{tabular}

${ }^{\mathrm{a}}$ This study; ${ }^{\mathrm{b}}$ Limbeck et al. (2001); ${ }^{\mathrm{c}}$ Aggarwal and Kawamura (2008); ${ }^{\mathrm{d}}$ Kawamura and Ikushima (1993); ${ }^{\mathrm{e}}$ Limbeck et al. (1999); ${ }^{\mathrm{f}}$ Pavuluri et al. (2010); ${ }^{\mathrm{g}}$ Hegde and Kawamura (2012); ${ }^{\mathrm{h}}$ Ho et al. (2006); ${ }^{\mathrm{i}}$ Kawamura et al. (2004).

Nainital and higher than those from Nylsvley (158.1 $\mathrm{ng} \mathrm{m}^{-3}$ ) and Salzburg $\left(61.7 \mathrm{ng} \mathrm{m}^{-3}\right)$. Predominance of oxalic acid $\left(\mathrm{C}_{2}\right)$ found at our site is consistent with other studies (Table 3) except for Salzburg where malonic acid $\left(C_{3}\right)$ was reported as the most abundant diacid. Oxalic acid is the end product of the photooxidation of aromatic hydrocarbons, isoprene, ethylene, and acetylene (Kawamura et al., 1996a; Lim et al., 2005) and may be emitted from biomass burning (Legrand and de Angelis, 1996; Kundu et al., 2010b). Concentration of $\mathrm{C}_{2}$ in Morogoro $\left(\mathrm{PM}_{10}\right)$ is several times higher than that of Nylsvley in South Africa, but comparable to those from Tokyo and Nainital (Table 3). Concentrations of $\mathrm{C}_{3}$ and $\mathrm{C}_{4}$ are comparable to those from Nainital, but lower than Chennai, Hong Kong and Jeju Is. Concentrations of $\mathrm{C}_{6}$ and $\mathrm{C}_{9}$ are comparable to those from megacities such as Tokyo, Chennai and Hong Kong, but lower than those from Sapporo and Jeju Island. Adipic acid $\left(\mathrm{C}_{6}\right)$ and azelaic acid $\left(\mathrm{C}_{9}\right)$ are tracers for anthropogenic and biogenic emissions, respectively (Kawamura and Ikushima, 1993).

On the other hand, predominance of fumaric acid over maleic acid at our site, in contrast to literature values in Table 3, suggests that the Morogoro aerosols contain aged oxidation products of aromatic hydrocarbons emitted from regional pollution sources. Concentrations of phthalic $(\mathrm{Ph})$ acid (mean: $13 \mathrm{ng} \mathrm{m}^{-3}$ ), a tracer for vehicle emissions (Kawamura and Ikushima, 1993) are about 2 folds lower than that from Chennai (mean: $21 \mathrm{ng} \mathrm{m}^{-3}$ ) and 7 folds lower than that from Hong Kong (mean: $84 \mathrm{ng} \mathrm{m}^{-3}$ ). We found that concentration of $\mathrm{tPh}$ acid in $\mathrm{PM}_{2.5}$ is similar to that reported from Sapporo (mean: $2.6 \mathrm{ng} \mathrm{m}^{-3}$, Aggarwal and Kawamura, 2008) but is lower than those from Chennai (mean: $52 \mathrm{ng} \mathrm{m}^{-3}$, Pavuruli et al., 2010) and Nainital (mean: $4.3 \mathrm{ng} \mathrm{m}^{-3}$, Hegde and Kawamura, 2012). tPh could be produced from open burning of solid waste (plastic) (Simoneit et al., 2005; Kawamura and Pavuluri, 2010), which occurs commonly in Tanzania. Concentrations of total ketoacids in Morogoro (mean: $38-54 \mathrm{ng} \mathrm{m}^{-3}$ ) with a predominance of $\omega \mathrm{C}_{2}$ are comparable to those from other sites whereas concentrations of total $\alpha$-dicarbonyls (mean: $5.7-7.8 \mathrm{ng} \mathrm{m}^{-3}$ ) are lower than those reported in the literature (Table 3). $\alpha$ Dicarbonyls may be more oxidized to result in oxalic acid (end product) in the rural site of Tanzania. 
Table 4. Correlation coefficients $\left(r^{2}\right)$ for selected diacids and related compounds in $\mathrm{PM}_{2.5}$ during wet season (upper diagonal triangle) and dry season (lower diagonal triangle) at Morogoro. Positive correlation coefficients $\geq 0.55$ are indicated in bold.

\begin{tabular}{|c|c|c|c|c|c|c|c|c|c|c|c|c|c|c|c|c|}
\hline & $\mathrm{C}_{2}$ & $\mathrm{C}_{3}$ & $\mathrm{C}_{4}$ & $\mathrm{iC}_{4}$ & $\mathrm{iC}_{5}$ & M & $\mathrm{F}$ & $\mathrm{mM}$ & $\mathrm{Ph}$ & Pyr & $\omega \mathrm{C}_{2}$ & $\omega \mathrm{C}_{3}$ & $\omega \mathrm{C}_{4}$ & $\omega \mathrm{C}_{9}$ & Gly & MeGly \\
\hline $\mathrm{C}_{2}$ & & 0.96 & 0.94 & 0.64 & 0.72 & 0.53 & 0.26 & 0.02 & -0.02 & 0.81 & 0.88 & 0.46 & & 0.09 & 0.53 & 0.66 \\
\hline $\mathrm{C}_{3}$ & 0.74 & & 0.98 & 0.69 & 0.78 & 0.50 & 0.25 & -0.42 & 0.13 & 0.81 & 0.94 & 0.51 & & 0.21 & 0.61 & 0.53 \\
\hline $\mathrm{C}_{4}$ & 0.88 & 0.76 & & 0.75 & 0.79 & 0.43 & 0.41 & -0.29 & 0.20 & 0.89 & 0.93 & 0.51 & & 0.17 & 0.67 & 0.72 \\
\hline $\mathrm{iC}_{5}$ & 0.63 & 0.58 & 0.86 & 0.33 & & 0.25 & 0.05 & -0.43 & -0.18 & 0.56 & 0.69 & 0.13 & & 0.03 & 0.25 & 0.55 \\
\hline $\mathrm{M}$ & -0.20 & -0.34 & -0.10 & 0.35 & -0.01 & & 0.05 & -0.04 & -0.13 & 0.33 & 0.30 & 0.36 & & 0.44 & 0.11 & -0.28 \\
\hline F & 0.45 & 0.09 & 0.38 & 0.10 & 0.41 & 0.19 & & 0.26 & 0.49 & 0.67 & 0.31 & 0.19 & & -0.08 & 0.71 & 0.01 \\
\hline Pyr & 0.38 & 0.20 & 0.49 & 0.60 & 0.31 & -0.05 & -0.04 & 0.26 & 0.31 & & 0.79 & 0.59 & & 0.00 & 0.72 & 0.70 \\
\hline$\omega \mathrm{C}_{2}$ & 0.90 & 0.67 & 0.66 & -0.06 & 0.31 & -0.28 & 0.36 & 0.15 & 0.55 & 0.24 & & 0.54 & & 0.28 & 0.76 & 0.68 \\
\hline$\omega \mathrm{C}_{3}$ & 0.74 & 0.46 & 0.52 & 0.22 & 0.07 & -0.34 & -0.02 & -0.02 & 0.58 & 0.47 & 0.82 & & & 0.61 & 0.39 & 0.45 \\
\hline$\omega \mathrm{C}_{4}$ & 0.27 & 0.37 & 0.48 & 0.31 & 0.28 & 0.72 & -0.16 & -0.20 & 0.79 & 0.56 & 0.24 & 0.34 & & NA & NA & NA \\
\hline$\omega \mathrm{C}_{9}$ & 0.25 & 0.75 & 0.25 & -0.30 & 0.03 & -0.36 & -0.25 & -0.24 & 0.58 & -0.07 & 0.39 & 0.26 & 0.41 & & 0.24 & 0.12 \\
\hline Gly & 0.84 & 0.38 & 0.76 & 0.30 & 0.53 & -0.01 & 0.50 & 0.28 & 0.46 & 0.54 & 0.79 & 0.70 & 0.38 & -0.10 & & 0.52 \\
\hline MeGly & 0.40 & 0.25 & 0.36 & 0.43 & 0.03 & 0.73 & -0.64 & -0.43 & 0.86 & 0.39 & -0.14 & 0.09 & 0.50 & 0.49 & 0.52 & \\
\hline
\end{tabular}

NA $=$ Not Available

Table 5. Correlation coefficients $\left(r^{2}\right)$ for selected diacids and related compounds in $\mathrm{PM}_{10}$ during wet season (upper diagonal triangle) and dry season (lower diagonal triangle) at Morogoro. Positive correlation coefficients $\geq 0.55$ are indicated in bold.

\begin{tabular}{|c|c|c|c|c|c|c|c|c|c|c|c|c|c|c|c|c|}
\hline & $\mathrm{C}_{2}$ & $\mathrm{C}_{3}$ & $\mathrm{C}_{4}$ & $\mathrm{iC}_{4}$ & $\mathrm{iC}_{5}$ & $\mathrm{M}$ & $\mathrm{F}$ & $\mathrm{mM}$ & $\mathrm{Ph}$ & Pyr & $\omega \mathrm{C}_{2}$ & $\omega \mathrm{C}_{3}$ & $\omega \mathrm{C}_{4}$ & $\omega \mathrm{C}_{9}$ & Gly & MeGly \\
\hline $\mathrm{C}_{2}$ & & 0.90 & 0.92 & -0.05 & 0.65 & 0.24 & 0.30 & 0.29 & 0.44 & 0.42 & 0.93 & 0.96 & 0.70 & -0.13 & 0.04 & 0.55 \\
\hline $\mathrm{C}_{3}$ & 0.94 & & 0.85 & 0.06 & 0.51 & 0.17 & 0.18 & 0.43 & 0.39 & 0.42 & 0.78 & 0.80 & 0.53 & 0.10 & -0.08 & 0.26 \\
\hline $\mathrm{C}_{4}$ & 0.95 & 0.95 & & -0.15 & 0.78 & 0.32 & 0.39 & 0.35 & 0.53 & 0.57 & 0.92 & 0.92 & 0.70 & -0.03 & 0.08 & 0.54 \\
\hline $\mathrm{iC}_{4}$ & 0.53 & 0.52 & 0.52 & & -0.26 & -0.29 & -0.44 & -0.16 & -0.30 & -0.28 & 0.00 & -0.19 & -0.17 & -0.14 & -0.40 & -0.48 \\
\hline $\mathrm{iC}_{5}$ & 0.92 & 0.91 & 0.96 & 0.55 & & 0.75 & 0.66 & 0.60 & 0.66 & 0.86 & 0.79 & 0.79 & 0.47 & -0.37 & 0.53 & 0.62 \\
\hline M & 0.95 & 0.99 & 0.97 & 0.46 & 0.94 & & 0.88 & 0.76 & 0.85 & 0.77 & 0.31 & 0.38 & 0.04 & -0.48 & 0.89 & 0.60 \\
\hline F & 0.92 & 0.93 & 0.98 & 0.43 & 0.91 & 0.95 & & 0.60 & 0.90 & 0.58 & 0.31 & 0.49 & 0.15 & -0.33 & 0.84 & 0.74 \\
\hline $\mathrm{mM}$ & 0.82 & 0.92 & 0.91 & 0.43 & 0.89 & 0.94 & 0.92 & & 0.57 & 0.73 & 0.29 & 0.08 & -0.17 & -0.01 & 0.64 & 0.21 \\
\hline $\mathrm{Ph}$ & 0.50 & 0.38 & 0.52 & -0.32 & 0.40 & 0.39 & 0.51 & 0.34 & & 0.62 & 0.41 & 0.53 & 0.27 & -0.36 & 0.72 & 0.74 \\
\hline Pyr & 0 & 0. & 0.63 & 0.42 & 0 & 0. & 0.74 & 0.7 & 0.5 & & 0.57 & 0.4 & 0.34 & - & 0.51 & 0.37 \\
\hline$\omega \mathrm{C}_{2}$ & 0.95 & 0.90 & 0.96 & 0.24 & 0.92 & 0.91 & 0.91 & 0.79 & 0.67 & 0.43 & & 0.94 & 0.76 & -0.25 & 0.10 & 0.55 \\
\hline$\omega \mathrm{C}_{3}$ & 0.93 & 0.85 & 0.92 & 0.22 & 0.81 & 0.85 & 0.91 & 0.70 & 0.69 & 0.45 & 0.95 & & 0.80 & -0.45 & 0.22 & 0.75 \\
\hline$\omega \mathrm{C}_{4}$ & 0.15 & 0.02 & 0.20 & -0.06 & 0.17 & -0.02 & 0.15 & -0.10 & 0.54 & -0.14 & 0.32 & 0.33 & & -0.32 & -0.12 & 0.47 \\
\hline$\omega \mathrm{C}_{9}$ & -0.29 & -0.36 & -0.36 & -0.63 & -0.23 & -0.33 & -0.52 & -0.45 & 0.13 & -0.70 & -0.15 & -0.31 & -0.18 & & -0.31 & -0.35 \\
\hline Gly & 0.9 & 0.9 & 0.94 & 0.21 & 0.83 & 0.91 & 0.92 & 0.80 & 0.68 & 0.58 & 0.95 & 0.96 & 0.20 & -0.26 & & 0.67 \\
\hline MeGly & 0.52 & 0.46 & 0.66 & 0.19 & 0.66 & 0.48 & 0.59 & 0.40 & 0.81 & -0.40 & 0.63 & 0.56 & 0.78 & 0.55 & 0.59 & \\
\hline
\end{tabular}

The $\mathrm{C}_{3} / \mathrm{C}_{4}$ ratio has been used to understand the photochemical processes and atmospheric production of diacids in the atmosphere (Kawamura and Ikushima, 1993; Aggarwal and Kawamura, 2008; Kundu et al., 2010b). At Morogoro the average $\mathrm{C}_{3} / \mathrm{C}_{4}$ ratios were 0.72 and 0.81 in $\mathrm{PM}_{2.5}$ and 1.3 and 1.0 in $\mathrm{PM}_{10}$ during the wet and dry seasons, respectively. The higher $\mathrm{C}_{3} / \mathrm{C}_{4}$ ratio in $\mathrm{PM}_{10}$ than in $\mathrm{PM}_{2.5}$ during wet season (see Table 1) may suggest that atmospheric oxidation of $\mathrm{C}_{4}$ to $\mathrm{C}_{3}$ is more significant under wetter conditions where heterogeneous processing may occur in aqueous aerosol phase of $\mathrm{PM}_{10}$. Although the differences in the ratios are not significant, wetter conditions under strong solar radiation may enhance the photochemical aging of organic aerosols in the tropical atmosphere. Based on the filed experiments, aqueous aerosol phase production of oxalic acid was reported in urban and suburban sites (Miyazaki et al., 2009;
He and Kawamura, 2010). However, when compared to literature values, our $\mathrm{C}_{3} / \mathrm{C}_{4}$ ratios are slightly lower than those (1.5) reported in Tokyo (Kawamura and Ikushima, 1993) and 1.4 in Chennai (Pavuluri et al., 2010) but comparable to those (0.84) in Nainital, India (Hegde and Kawamura, 2012) and those (1.3) in Jeju Island in the East China Sea (Kawamura et al., 2004).

\subsection{Source identification of diacids, ketoacids and $\alpha$-dicarbonyls}

Correlation matrix for diacids and related compounds in $\mathrm{PM}_{2.5}$ and $\mathrm{PM}_{10}$ during the 2011 wet and dry seasons are given in Tables 4 and 5, respectively. Many combinations of different compounds exhibit strong correlations in both seasons and sizes, suggesting common sources and/or similar formation mechanisms. In $\mathrm{PM}_{2.5}, \mathrm{C}_{2}$ showed a strong 
Table 6. Correlation coefficients $\left(r^{2}\right)$ for selected diacids and related compounds against source tracers (organic carbon, OC; elemental carbon, EC; non-sea-salt potassium, $\mathrm{nss}^{+} \mathrm{K}^{+}$, and levoglucosan, $\mathrm{LG}$ ) in $\mathrm{PM}_{2.5}$ and $\mathrm{PM}_{10}$ during wet and dry seasons at Morogoro. Correlation $\geq 0.55$ are bolded.

\begin{tabular}{|c|c|c|c|c|c|c|c|c|c|c|c|c|c|c|c|c|}
\hline \multirow[t]{3}{*}{ Species } & \multicolumn{8}{|c|}{$\mathrm{PM}_{2.5}$} & \multicolumn{8}{|c|}{$\mathrm{PM}_{10}$} \\
\hline & \multicolumn{4}{|c|}{ Wet season } & \multicolumn{4}{|c|}{ Dry season } & \multicolumn{4}{|c|}{ Wet season } & \multicolumn{4}{|c|}{ Dry season } \\
\hline & $\mathrm{OC}$ & $\mathrm{EC}$ & Nss-K ${ }^{+}$ & LG & $\mathrm{OC}$ & $\mathrm{EC}$ & Nss-K ${ }^{+}$ & LG & OC & $\mathrm{EC}$ & Nss-K ${ }^{+}$ & LG & $\mathrm{OC}$ & $\mathrm{EC}$ & Nss-K ${ }^{+}$ & LG \\
\hline $\mathrm{C}_{2}$ & 0.46 & 0.76 & -0.20 & 0.66 & 0.75 & 0.27 & 0.74 & 0.66 & 0.68 & 0.76 & 0.65 & 0.57 & 0.75 & 0.90 & 0.65 & 0.78 \\
\hline $\mathrm{C}_{3}$ & 0.55 & 0.77 & -0.09 & 0.69 & 0.79 & 0.28 & 0.51 & 0.43 & 0.61 & 0.60 & 0.47 & 0.54 & 0.61 & 0.90 & 0.53 & 0.69 \\
\hline $\mathrm{C}_{4}$ & 0.63 & 0.83 & -0.10 & 0.72 & 0.87 & 0.54 & 0.77 & 0.74 & 0.85 & 0.86 & 0.74 & 0.68 & 0.69 & 0.95 & 0.51 & 0.74 \\
\hline $\mathrm{iC}_{4}$ & 0.58 & 0.69 & -0.25 & 0.33 & 0.13 & 0.16 & 0.17 & 0.18 & -0.27 & -0.32 & -0.01 & -0.12 & 0.04 & 0.31 & -0.17 & 0.20 \\
\hline $\mathrm{iC}_{5}$ & 0.48 & 0.76 & -0.11 & 0.96 & 0.87 & 0.55 & 0.65 & 0.85 & 0.79 & 0.79 & 0.56 & 0.70 & 0.69 & 0.93 & 0.43 & 0.80 \\
\hline$M$ & -0.18 & 0.40 & -0.66 & 0.29 & -0.06 & 0.20 & 0.12 & 0.16 & 0.32 & 0.28 & -0.09 & 0.22 & 0.64 & 0.91 & 0.51 & 0.72 \\
\hline $\mathrm{F}$ & 0.35 & 0.62 & -0.09 & 0.07 & 0.27 & 0.34 & 0.54 & 0.48 & 0.34 & 0.24 & -0.10 & 0.10 & 0.63 & 0.92 & 0.45 & 0.65 \\
\hline $\mathrm{mM}$ & -0.11 & -0.19 & -0.02 & -0.29 & 0.40 & -0.23 & 0.28 & 0.54 & 0.20 & 0.18 & -0.18 & 0.16 & 0.59 & 0.88 & 0.41 & 0.68 \\
\hline $\mathrm{Ph}$ & 0.49 & 0.09 & 0.23 & -0.20 & 0.70 & 0.49 & 0.50 & 0.37 & 0.43 & 0.35 & 0.03 & 0.20 & 0.55 & 0.43 & 0.55 & 0.43 \\
\hline$\omega \mathrm{C}_{2}$ & 0.69 & 0.68 & -0.01 & 0.58 & 0.58 & 0.21 & 0.70 & 0.45 & 0.77 & 0.87 & 0.78 & 0.66 & 0.72 & 0.87 & 0.60 & 0.76 \\
\hline$\omega \mathrm{C}_{3}$ & 0.32 & 0.25 & 0.22 & 0.08 & 0.30 & 0.02 & 0.43 & 0.16 & 0.80 & 0.85 & 0.77 & 0.64 & 0.65 & 0.82 & 0.59 & 0.61 \\
\hline$\omega \mathrm{C}_{4}$ & NA & NA & NA & NA & 0.50 & 0.57 & 0.57 & 0.34 & 0.64 & 0.75 & 0.72 & 0.48 & 0.21 & 0.23 & 0.04 & 0.18 \\
\hline$\omega \mathrm{C}_{9}$ & 0.17 & -0.03 & -0.17 & 0.03 & 0.33 & 0.20 & 0.12 & -0.15 & -0.09 & -0.12 & -0.16 & -0.18 & 0.05 & -0.31 & 0.19 & 0.06 \\
\hline Pyr & 0.64 & 0.87 & 0.02 & 0.51 & 0.38 & 0.08 & 0.46 & 0.36 & 0.58 & 0.59 & 0.34 & 0.53 & 0.30 & 0.43 & 0.32 & 0.26 \\
\hline Gly & 0.68 & 0.56 & 0.05 & 0.18 & 0.64 & 0.42 & 0.88 & 0.73 & 0.04 & 0.13 & -0.30 & -0.10 & 0.69 & 0.84 & 0.66 & 0.67 \\
\hline MeGly & 0.72 & 0.33 & 0.11 & 0.58 & -0.27 & 0.22 & -0.28 & -0.42 & 0.42 & 0.58 & 0.29 & 0.18 & 0.71 & 0.63 & 0.33 & 0.63 \\
\hline
\end{tabular}

NA $=$ Not Available

positive correlation with its precursors $\mathrm{C}_{3}, \mathrm{C}_{4}, \mathrm{iC}_{5}$ and $\omega \mathrm{C}_{2}$ in both seasons, with $\mathrm{iC}_{4}$, $\mathrm{Pyr}$, and MeGly in the wet season, and with $\mathrm{Ph}, \omega \mathrm{C}_{3}$, and Gly in the dry season. Glyoxylic acid $\left(\omega \mathrm{C}_{2}\right)$ correlated with Pyr in the wet season and with Gly in the dry season. These correlations suggest a possible production of $\mathrm{C}_{2}$ from aromatic hydrocarbons because Pyr and Gly may be oxidation products of aromatics. In $\mathrm{PM}_{10}, \mathrm{C}_{2}$ correlated with its precursor compounds $\mathrm{C}_{3}, \mathrm{C}_{4}, \mathrm{iC}_{5}, \omega \mathrm{C}_{2}$ and $\omega \mathrm{C}_{3}$ in both seasons, with $\omega \mathrm{C}_{4}$ and MeGly in wet season, and with Pyr and Gly in dry season. $\omega \mathrm{C}_{2}$ correlated with $\mathrm{C}_{2}$, $\mathrm{C}_{3}, \mathrm{C}_{4}$ and $\mathrm{iC}_{5}$ in both seasons, with Pyr in the wet season, and with Gly and MeGly in the dry season. These correlations further suggest that $\mathrm{C}_{2}$ may be formed through chain reactions of other diacids and related compounds.

Levoglucosan (1,6-Anhydro- $\beta$-D-glucopyranose), watersoluble $\mathrm{K}^{+}$and organic carbon (OC) are used as source tracers for biomass burning and elemental carbon (EC) for biofuel combustion (Cachier et al., 1991, 1995; Andreae and Merlet, 2001; Puxbaum et al., 2007; Zhang et al., 2008). Table 6 shows correlation coefficients for selected diacids and related compounds against those source tracers in $\mathrm{PM}_{2.5}$ and $\mathrm{PM}_{10}$ during the wet and dry seasons. We found strong correlations between the source tracers and diacids $\left(\mathrm{C}_{2}-\mathrm{C}_{4}\right)$, $\mathrm{iC}_{5}$ and $\omega \mathrm{C}_{2}$ (in both season), $\mathrm{iC}_{4}, \mathrm{~F}, \mathrm{Pyr}$ and MeGly (in wet season) and $\mathrm{Ph}$ (in dry season) in both $\mathrm{PM}_{2.5}$ and $\mathrm{PM}_{10}$. The source tracers also strongly correlated with Gly in $\mathrm{PM}_{2.5}$ and $\omega \mathrm{C}_{3}$ in $\mathrm{PM}_{10}$ during both seasons, $\mathrm{F}$ in $\mathrm{PM}_{2.5}$ during the wet season, $\mathrm{M}, \mathrm{F}, \mathrm{mM}$, Gly and MeGly in $\mathrm{PM}_{10}$ during the dry season. These correlations suggest that the diacids, ketoacids and $\alpha$-dicarbonyls are partly produced from biomass and biofuel burning in both seasons. Previous studies have reported a good correlation between biomass/biofuel burning tracers
$\left(\mathrm{K}^{+}\right.$and EC) and diacids and related compounds (Graham et al., 2002; Kundu et al., 2010a).

Mean ratios of $\mathrm{C}_{2}$ to $\mathrm{C}_{4}$ and $\mathrm{C}_{5}$ at our site can be compared with the ratios in biomass burning aerosols. The $\mathrm{C}_{2} / \mathrm{C}_{4}$ ratios in $\mathrm{PM}_{2.5}$ were $7.0-8.3$ whereas $\mathrm{C}_{2} / \mathrm{C}_{5}$ were $8.8-56.3$ during both seasons. Those values from this study are much higher than those $\left(\mathrm{C}_{2} / \mathrm{C}_{4}: 1.6\right.$ and $\left.\mathrm{C}_{2} / \mathrm{C}_{5}: 2.5\right)$ reported in aerosols associated with savannah fires in Southern Africa (Gao et al., 2003). These comparisons suggest a secondary formation of $\mathrm{C}_{2}$ from $\mathrm{C}_{4}$ and $\mathrm{C}_{5}$ diacids. Concentration ratios of $\mathrm{C}_{2}$ and $\mathrm{C}_{4}$ to non-sea-salt potassium (nss- $\mathrm{K}^{+}$) and levoglucosan (LG) were generally higher $\left(\mathrm{C}_{2} / \mathrm{K}^{+} ; 0.15-0.31\right.$, $\mathrm{C}_{2} / \mathrm{LG} ; 0.81-1.02, \mathrm{C}_{4} / \mathrm{K}^{+} ; 0.02-0.04$, and $\mathrm{C}_{4} / \mathrm{LG} ; 0.10-$ $0.14)$ than those $\left(\mathrm{C}_{2} / \mathrm{K}^{+} ; 0.05, \mathrm{C}_{2} / \mathrm{LG} ; 0.05, \mathrm{C}_{4} / \mathrm{K}^{+} ; 0.03\right.$, and $\mathrm{C}_{4} / \mathrm{LG}$; 0.03 ) reported for the smoke aerosols collected in southern Africa savannah fires (Gao et al., 2003). These comparisons suggest that, in addition to the emission of $\mathrm{C}_{2}$ and $\mathrm{C}_{4}$ diacids from biomass burning (Gao et al., 2003; Sillanpää et al., 2005), photochemical production of these diacids is significantly important in the Tanzanian aerosols.

We assessed the relations between total diacids with $\mathrm{Na}^{+}$, $\mathrm{EC}$, nss- $\mathrm{K}^{+}$and $\mathrm{LG}$ in $\mathrm{PM}_{2.5}$ and $\mathrm{PM}_{10}$ during the wet and dry seasons. Although the air masses often originated from the Indian Ocean during the campaigns, total diacids were poorly correlated with $\mathrm{Na}^{+}$(tracer for sea-salt) in both seasons (Fig. 9a, b), suggesting that contributions of diacids from sea-salt aerosols are insignificant. Biomass burning has been reported to be an important source of diacids and related compounds (Kundu et al., 2010a). Strong correlations were found between total diacids with EC (Fig. 9c, d) and nss-K ${ }^{+}$ and LG especially in the dry season (Fig. 10a-d). These relations suggest that biofuel combustion and biomass burning 

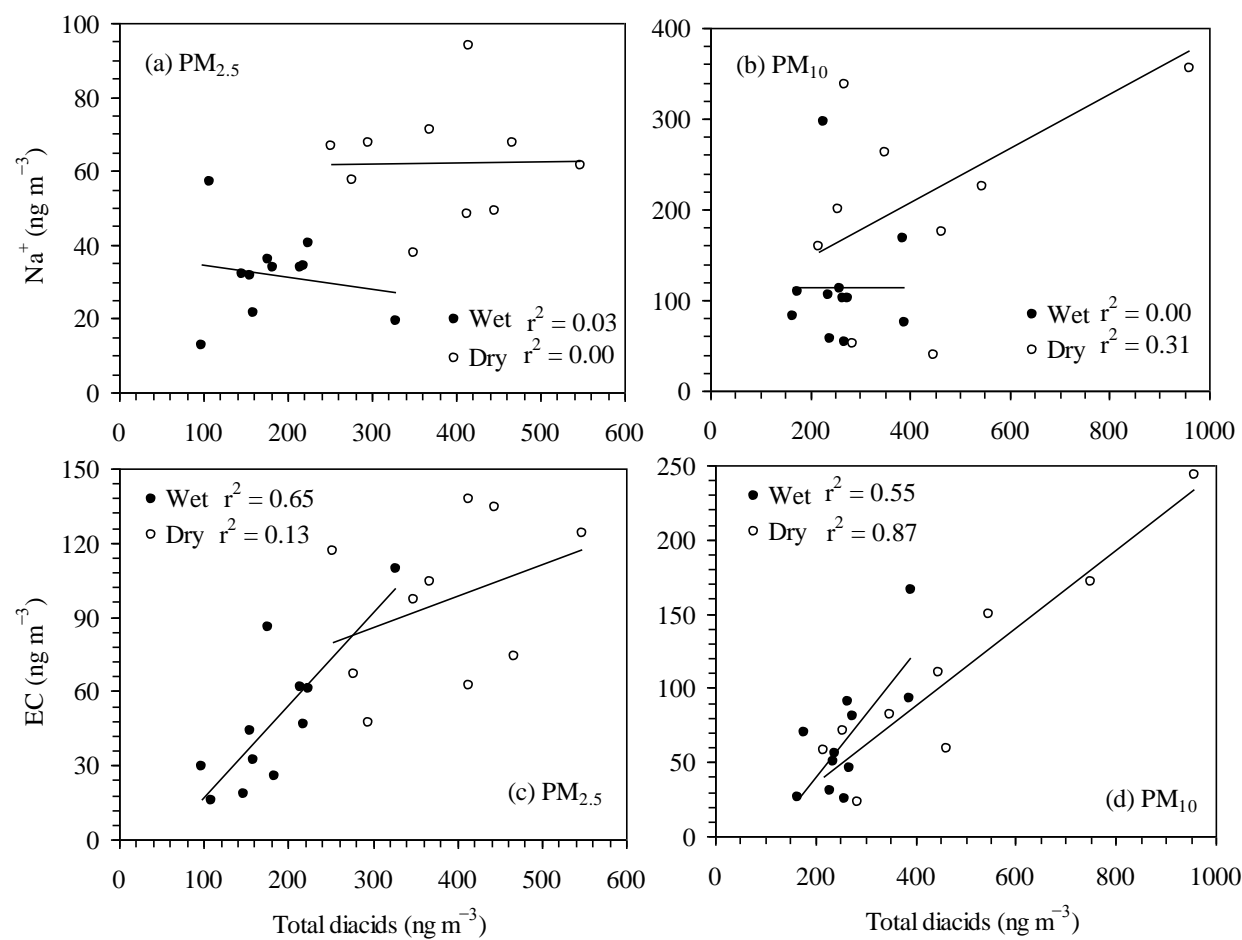

Fig. 9. Correlation between total diacids with $\mathrm{Na}^{+}$and $\mathrm{EC}$ in $\mathrm{PM}_{2.5}(\mathbf{a}, \mathbf{c})$ and $\mathrm{PM}_{10}(\mathbf{b}, \mathbf{d})$ at Morogoro during the wet and dry seasons.
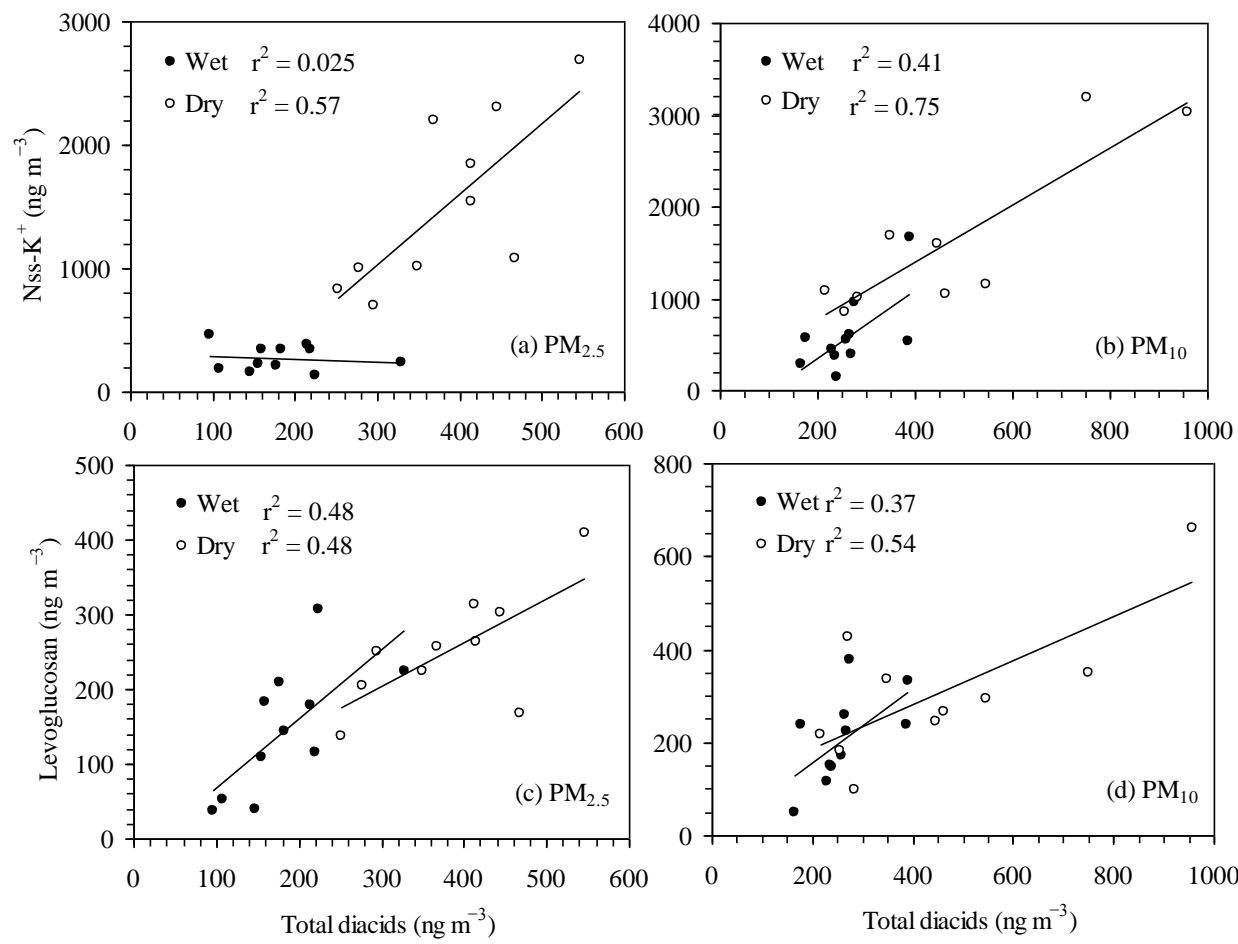

Fig. 10. Relations between total diacids with nss- $\mathrm{K}^{+}$and levoglucosan in $\mathrm{PM}_{2.5}(\mathbf{a}, \mathbf{c})$ and $\mathrm{PM}_{10}(\mathbf{b}$, d) during the wet and dry seasons in Morogoro. 
significantly contribute to the water-soluble organic species in the aerosols from Tanzania.

On the other hand, nss- $\mathrm{K}^{+}$showed no correlation with total diacids in $\mathrm{PM}_{2.5}$ during the wet season (Fig. 10a), although a weak correlation was found for $\mathrm{PM}_{10}$ (Fig. 10b). However, levoglucosan showed a positive relation with total diacids in both wet and dry season (Fig. 10c, d). The above apparent discrepancy may suggest that $n s s-\mathrm{K}^{+}$can only be produced by flaming process during dry season but not by smoldering process during wet season whereas levoglucosan can be produced by both modes of the burning processes to result in aerosol particles.

\section{Summary and conclusions}

We determined low molecular weight diacids, ketoacids and $\alpha$-dicarbonyls, and fatty acids in atmospheric aerosol samples collected from a rural site in Tanzania during the wet and dry seasons. The results on both $\mathrm{PM}_{2.5}$ and $\mathrm{PM}_{10}$ showed that oxalic acid $\left(\mathrm{C}_{2}\right)$ was the dominant diacid species whereas glyoxylic acid $\left(\omega \mathrm{C}_{2}\right)$ and glyoxal (Gly) were the most abundant ketoacid and $\alpha$-dicarbonyl, respectively. Fatty acids with even carbon number were detected with a peak at myristic acid $\left(\mathrm{C}_{14: 0}\right)$ in $\mathrm{PM}_{2.5}$ and palmitic acid $\left(\mathrm{C}_{16: 0}\right)$ in $\mathrm{PM}_{10}$ in both seasons, indicating significant influences from biological sources. The mass concentrations of diacids, ketoacids and fatty acids were higher during the dry season than the wet season. They are mainly present in fine particles $\left(\mathrm{PM}_{2.5}\right)$, suggesting a larger contribution of pyrogenically produced organic acids and enhanced photochemical processing in the dry season due to strong solar radiation. Relatively high ratios of diacid-C/TC and diacid-C/WSOC further indicate a strong influence of photochemical oxidation of organic precursors in the atmosphere. Nss- $\mathrm{K}^{+}$(biomass-burning tracer) showed different regression patterns with total diacids in $\mathrm{PM}_{2.5}$ during the wet and dry seasons, but levoglucosan (another biomass-burning tracer) showed a positive correlation with total diacids in both seasons. The difference between the two tracers may be caused by the different behaviour during biomass burning processes; $\mathrm{K}^{+}$may be produced only by flaming process whereas both flaming and smoldering processes produce levoglucosan. Strong correlations between organic components and source tracers in $\mathrm{PM}_{2.5}$ and $\mathrm{PM}_{10}$ during both wet and dry seasons suggest common sources (e.g., biomass and biofuel burning) and/or similar formation pathways for water-soluble dicarboxylic acids in the rural site of Tanzania, East Africa.

Acknowledgements. This study was in part supported by the Japanese Ministry of Education, Culture, Sports, Science and Technology (MEXT) through grant-in-aid No. 24221001 and the Environment Research and Technology Development Fund (B-0903) from the Ministry of the Environment, Japan. The authors acknowledge the financial support by the Japan Society for the Promotion of Science (JSPS) to first author. We thank Filbert T. Sogomba of the Department of Physical Sciences (SUA) for sample collection. The authors also thank the NOAA Air Resources Laboratory (ARL) for the provision of the HYSPLIT transport and dispersion model and/or READY website (http://www.arl.noaa.gov/ready.php) used in this publication.

Edited by: V.-M. Kerminen

\section{References}

Aggarwal, S. G. and Kawamura, K.: Molecular distributions and stable carbon isotopic compositions of dicarboxylic acids and related compounds in aerosols from Sapporo, Japan: Implications for photochemical aging during longrange atmospheric transport, J. Geophys. Res., 113, D14301, doi:10.1029/2007JD009365, 2008.

Alfarra, M. R., Coe, H., Allan, J. D., Bower, K. N., Boudries, H., Canagaratna, M. R., Jimenez, J. L., Jayne, J. T., Garforth, A., Li, S.-M., and Worsnop, D. R.: Characteristics of urban and rural organic particulate in the Lower Fraser Valley using two aerodyne aerosol mass spectrometers, Atmos. Environ., 38, 57455758, 2004.

Andreae, M. O. and Merlet, P.: Emission of trace gases and aerosols from biomass burning, Global Biogeochem. Cy., 15, 955-966, 2001.

Cachier, H., Ducret, J., Brémond, M. P., Gaudichet, A., Lacaux, J. P., Yoboué, V., and Baudet, J.: Biomass burning in a savanna region of the Ivory Coast, in: Global Biomass Burning: Atmospheric, Climatic and Biospheric Implications, edited by: Levine, J. S., MIT Press, Cambridge, Mass., 174-180, 1991.

Cachier, H., Liousse, C., Buat-Menard, P., and Gaudichet, A.: Particulate content of savanna fire emissions, J. Atmos. Chem., 22, 123-148, 1995.

Carlton, A. G., Turpin, B. J., Lim, H.-J., Altieri, K. E., and Seitzinger, S.: Link between isoprene and secondary organic aerosol (SOA): Pyruvic acid oxidation yields low volatility organic acids in clouds, Geophys. Res. Lett., 33, L06822, doi:10.1029/2005GL025374, 2006.

Cheng, Y., Li, S.-M., Leithead, A., Brickell, P. C., and Richard Leaitch, W.: Characterizations of cis-pinonic acid and n-fatty acids on fine aerosols in the Lower Fraser Valley during Pacific 2001 air quality study, Atmos. Environ., 38, 5789-5800, 2004.

Claeys, M., Graham, B., Vas, G., Wang, W., Vermeylen, R., Pashynska, V., Cafmeyer, J., Guyon, P., Andreae, M. O., Artaxo, P., and Maenhaut, W.: Formation of secondary organic aerosols through photooxidation of isoprene, Science, 303, 1173-1176, 2004.

Draxler, R. R. and Rolph, G. D.: HYSPLIT (HYbrid Single-Particle Lagrangian Integrated Trajectory) Model access via NOAA ARL READY Website (http://ready.arl.noaa.gov/HYSPLIT.php), last access: 29 May 2012, NOAA Air Resources Laboratory, Silver Spring, MD, 2012.

Ervens, B., Feingold, G., Frost, G. J., and Kreidenweis, S. M.: A modelling study of aqueous production of dicarboxylic acids: 1 . Chemical pathways and speciated organic mass production, J. Geophys. Res., 109, D15205, doi:10.1029/2003JD004387, 2004. Falkovich, A. H., Graber, E. R., Schkolnik, G., Rudich, Y., Maenhaut, W., and Artaxo, P.: Low molecular weight organic acids in aerosol particles from Rondônia, Brazil, during the 
biomass-burning, transition and wet periods, Atmos. Chem. Phys., 5, 781-797, doi:10.5194/acp-5-781-2005, 2005.

Fick, J., Nilsson, C., and Andersson, B.: Formation of oxidation products in a ventilation system, Atmos. Environ., 38, 58955899, 2004.

Gao, S., Hegg, D. A., Hobbs, P. V., Kirchstetter, T. W., Magi, B. I., and Sadilek, M.: Water-soluble organic components in aerosols associated with savanna fires in southern Africa: Identification, evolution, and distribution, J. Geophys. Res., 108, 8491, doi:10.1029/2002JD002324, 2003.

Gierlus, K. M., Laskina, O., Abernathy, T. L., and Grassian, V. H.: Laboratory study of the effect of oxalic acid on the cloud condensation nuclei activity of mineral dust aerosol, Atmos. Environ., 46, 125-130, 2012.

Graham, B., Mayol-Bracero, O. L., Guyon, P., Roberts, G. C., Decesari, S., Facchini, M. C., Artaxo, P., Maenhaut, W., Koll, P., and Andreae, M. O.: Water-soluble organic compounds in biomass burning aerosols over Amazonia. 1. Characterization by NMR and GC-MS, J. Geophys. Res., 107, 8047, doi:10.1029/2001JD000336, 2002.

Guenther, A., Karl, T., Harley, P., Wiedinmyer, C., Palmer, P. I., and Geron, C.: Estimates of global terrestrial isoprene emissions using MEGAN (Model of Emissions of Gases and Aerosols from Nature), Atmos. Chem. Phys., 6, 3181-3210, doi:10.5194/acp-63181-2006, 2006.

$\mathrm{He}$, N. and Kawamura, K.: Distributions and diurnal changes of low molecular weight organic acids and $\alpha$-dicarbonyls in suburban aerosols collected at Mangshan, North China, Geochem. J., 44, E17-E22, 2010.

Hegde, P. and Kawamura, K.: Seasonal variations of water-soluble organic carbon, dicarboxylic acids, ketocarboxylic acids, and $\alpha$ dicarbonyls in Central Himalayan aerosols, Atmos. Chem. Phys., 12, 6645-6665, doi:10.5194/acp-12-6645-2012, 2012.

Highwood, E. J. and Kinnersley, R. P.: When smoke gets in our eyes: The multiple impacts of atmospheric black carbon on climate, air quality and health, Environ. Int., 32, 560-566, 2006.

Ho, K. F., Lee, S. C., Cao, J. J., Kawamura, K., Watanabe, T., Cheng, Y., and Chow, J. C.: Dicarboxylic acids, ketocarboxylic acids and dicarbonyls in the urban roadside area of Hong Kong, Atmos. Environ., 40, 3030-3040, 2006.

Ho, K. F., Cao, J. J., Lee, S. C., Kawamura, K., Zhang, R. J., Chow, J. C., and Watson, J. G.: Dicarboxylic acids, ketocarboxylic acids, and dicarbonyls in the urban atmosphere of China, J. Geophys. Res., 112, D22S27, doi:10.1029/2006JD008011, 2007.

Ho, K. F., Lee, S. C., Ho, S. S. H., Kawamura, K., Tachibana, E., Cheng, Y., and Zhu, T.: Dicarboxylic acids, ketocarboxylic acids, $\alpha$-dicarbonyls, fatty acids, and benzoic acid in urban aerosols collected during the 2006 Campaign of Air Quality Research in Beijing (CAREBeijing-2006), J. Geophys. Res., 115, D19312, doi:10.1029/2009jd013304, 2010.

Hsieh, L.-Y., Chen, C.-L., Wan, M.-W., Tsai, C.-H., and Tsai, Y.-I.: Speciation and temporal characterization of dicarboxylic acids in $\mathrm{PM}_{2.5}$ during a PM episode and a period of non-episodic pollution, Atmos. Environ., 42, 6836-6850, 2008.

Hyder, M., Genberg, J., Sandahl, M., Swietlicki, E., and Jönsson, J.-A.: Yearly trend of dicarboxylic acids in organic aerosols from south of Sweden and source attribution, Atmos. Environ., 57, 197-204, 2012.
Jung, J., Tsatsral, B., Kim, Y. J., and Kawamura, K.: Organic and inorganic aerosol compositions in Ulaanbaatar, Mongolia, during the cold winter of 2007 to 2008: Dicarboxylic acids, ketocarboxylic acids, and $\alpha$-dicarbonyls, J. Geophys. Res., 115, D22203, doi:10.1029/2010JD014339, 2010.

Kassim, S. M.: Sustainability of private sector in solid waste collection-A case of Dar es Salaam, Tanzania, Ph.D. thesis, Civil and Building Engineering, WEDC, Loughborough University, United Kingdom, Loughborough, 347 pp., 2006.

Kawamura, K. and Gagosian, R. B.: Implications of $\omega$ oxocarboxylic acids in the remote marine atmosphere for photooxidation of unsaturated fatty acids, Nature, 325, 330-332, 1987.

Kawamura, K. and Ikushima, K.: Seasonal changes in the distribution of dicarboxylic acids in the urban atmosphere, Environ. Sci. Technol., 27, 2227-2235, 1993.

Kawamura, K. and Kaplan, I. R.: Motor exhaust emission as a primary source of dicarboxylic acids in Los Angeles ambient air, Environ. Sci. Technol., 21, 105-110, 1987.

Kawamura, K. and Pavuluri, C. M.: New directions: Need for better understanding of plastic waste burning as inferred from high abundance of terephthalic acid in South Asian aerosols, Atmos. Environ., 44, 5320-5321, 2010.

Kawamura, K. and Sakaguchi, F.: Molecular distributions of water soluble dicarboxylic acids in marine aerosols over the Pacific Ocean including tropic, J. Geophys. Res., 104, 3501-3509, 1999.

Kawamura, K. and Yasui, O.: Diurnal changes in the distribution of dicarboxylic acids, ketocarboxylic acids and dicarbonyls in the urban Tokyo atmosphere, Atmos. Environ., 39, 1945-1960, 2005.

Kawamura, K., Kasukabe, H., and Barrie, L. A.: Source and reaction pathways of dicarboxylic acids, ketoacids and dicarbonyls in arctic aerosols: One year of observations, Atmos. Environ. 30, 1709-1722, 1996a.

Kawamura, K., Sempéré, R., Imai, Y., Hayashi, M., and Fujii, Y.: Water soluble dicarboxylic acids and related compounds in the Antarctic aerosols, J. Geophys. Res., 101, 18721-18728, 1996b.

Kawamura, K., Umemoto, N., Mochida, M., Bertram, T., Howell, S., and Huebert, B. J.: Water-soluble dicarboxylic acids in the tropospheric aerosols collected over east Asia and western North Pacific by ACE-Asia C-130 aircraft, J. Geophys. Res., 108, 8639, doi:10.1029/2002JD003256, 2003.

Kawamura, K., Kobayashi, M., Tsubonuma, N., Mochida, M., Watanabe, T., and Lee, M.: Organic and inorganic compositions of marine aerosols from East Asia: Seasonal variations of water soluble dicarboxylic acids, major ions, total carbon and nitrogen, and stable $\mathrm{C}$ and $\mathrm{N}$ isotopic composition, in: Geochemical Investigation in Earth and Space Science; A Tribute to Issac R. Kaplan, The Geochemical Society Special Publication Series, Vol. 9, edited by: Hill, R. J., 243-265, Elsevier, Amsterdam, Netherlands, 2004.

Kawamura, K., Narukawa, M., Li, S. M., and Barrie, L. A.: Size distributions of dicarboxylic acids and inorganic ions in atmospheric aerosols collected during polar sunrise in the Canadian high Arctic, J. Geophys. Res., 112, D10307, doi:10.1029/2006JD008244, 2007.

Kawamura, K., Kasukabe, H., and Barrie, L. A.: Secondary formation of water-soluble organic acids and $\alpha$-dicarbonyls and their contribution to total carbon and water-soluble organic carbon: Photochemical ageing of organic aerosols in the Arctic spring, J. 
Geophys. Res., 115, D21306, doi:10.1029/2010JD014299, 2010.

Kawamura, K., Ono, K., Tachibana, E., Charriére, B., and Sempéré, R.: Distributions of low molecular weight dicarboxylic acids, ketoacids and $\alpha$-dicarbonyls in the marine aerosols collected over the Arctic Ocean during late summer, Biogeosciences, 9, 47254737, doi:10.5194/bg-9-4725-2012, 2012.

Kerminen, V.-M., Ojanen, C., Pakkanen, T., Hillamo, R., Aurela, M., and Merilainen, J.: Low-molecular weight dicarboxylic acids in an urban and rural atmosphere, J. Aerosol. Sci., 31, 349-362, 2000.

Kundu, S., Kawamura, K., Andreae, T. W., Hoffer, A., and Andreae, M. O.: Molecular distributions of dicarboxylic acids, ketocarboxylic acids and $\alpha$-dicarbonyls in biomass burning aerosols: implications for photochemical production and degradation in smoke layers, Atmos. Chem. Phys., 10, 2209-2225, doi:10.5194/acp-10-2209-2010, 2010a.

Kundu, S., Kawamura, K., and Lee, M.: Seasonal variations of diacids, ketoacids and $\alpha$-dicarbonyls in marine aerosols at Gosan, Jeju Island: Implications for their formation and degradation during long-range transport, J. Geophys. Res., 115, D19307, doi:10.1029/2010JD013973, 2010b.

Lechevalier, M. F.: Lipids in bacterial taxonomy-a taxonomist's view, CRC Crit. Rev. Microbiol., 5, 109-210, 1977.

Legrand, M. and de Angelis, M.: Light carboxylic acids in Greenland ice: A record of past forest fires and vegetation emissions from the boreal zone, J. Geophys. Res.-Atmos., 101, 4129-4145, 1996.

Lim, H.-J., Carlton, A. G., and Turpin, B. J.: Isoprene forms secondary organic aerosol through cloud processing: Model simulations, Environ. Sci. Technol., 39, 4441-4446, 2005.

Limbeck, A. and Puxbaum, H.: Organic acids in continental background aerosols, Atmos. Environ., 33, 1847-1852, 1999.

Limbeck, A., Puxbaum, H., Otter, L., and Scholes, M. C.: Semivolatile behavior of dicarboxylic acids and other polar organic species at a rural background site (Nylsvley, RSA), Atmos. Environ., 35, 1853-1862, 2001.

Limbeck, A., Kraxner, Y., and Puxbaum, H.: Gas to particle distribution of low molecular weight dicarboxylic acids at two different sites in central Europe (Austria), J. Aeros. Sci., 36, 991-1005, 2005.

Maenhaut, W., Francois, F., and Cafmeyer, J.: The Gent stacked filter unit sampler for the collection of atmospheric aerosols in two size fractions: description and instructions for installation and use, in: Applied Research on Air Pollution Using Nuclearrelated Analytical Techniques, IAEA Report NAHRES-19, Vienna, 249-263, 1994.

McFiggans, G., Alfarra, M. R., Allan, J. D., Bower, K. N., Coe, H., Cubison, M., Topping, D. O., Williams, P. I., Decesari, S., Facchini, M. C., and Fuzzi, S.: Simplification of the representation of the organic component of atmospheric particulates, Faraday Discuss., 130, 1-22, 2005.

Miyazaki, Y., Aggarwal, S. G., Singh, K., Gupta, P. K., and Kawamura, K.: Dicarboxylic acids and water-soluble organic carbon in aerosols in New Delhi, India, in winter: Characteristics and formation processes, J. Geophys. Res.-Atmos., 114, D19206, doi:10.1029/2009JD011790, 2009.

Mkoma, S. L., Maenhaut, W., Chi, X., Wang, W., and Raes, N.: Chemical composition and mass closure for $\mathrm{PM}_{10}$ aerosols during the 2005 dry season at a rural site in Morogoro, Tanzania,
X-Ray Spectrom., 38, 293-300, 2009.

Mkoma, S. L., Kawamura, K., and Fu, P.: Carbonaceous components, levoglucosan and inorganic ions in tropical aerosols from Tanzania, East Africa: implication for biomass burning contribution to organic aerosols, Atmos. Chem. Phys. Discuss., 12, 28661-28703, doi:10.5194/acpd-12-28661-2012, 2012.

Mochida, M., Umemoto, N., Kawamura, K., Lim, H.-J., and Turpin, B. J.: Bimodal size distributions of various organic acids and fatty acids in the marine atmosphere: Influence of anthropogenic aerosols, Asian dusts, and sea spray off the coast of East Asia, J. Geophys. Res., 112, D15209, doi:10.1029/2006JD007773, 2007.

Myriokefalitakis, S., Tsigaridis, K., Mihalopoulos, N., Sciare, J., Nenes, A., Kawamura, K., Segers, A., and Kanakidou, M.: In-cloud oxalate formation in the global troposphere: a 3-D modeling study, Atmos. Chem. Phys., 11, 5761-5782, doi:10.5194/acp-11-5761-2011, 2011.

Narukawa, M., Kawamura, K., Takeuchi, N., and Nakajima, T.: Distribution of dicarboxylic acids and carbon isotopic compositions in aerosols from 1997 Indonesian forest fires, Geophys. Res. Lett., 26, 3101-3104, 1999.

Narukawa, M., Kawamura, K., Anlauf, K. G., and Barrie, L. A.: Fine and coarse modes of dicarboxylic acids in the arctic aerosols collected during the Polar Sunrise Experiment 1997, J. Geophys. Res., 108, 4575, doi:10.1029/2003JD003646, 2003.

Pavuluri, C. M., Kawamura, K., and Swaminathan, T.: Watersoluble organic carbon, dicarboxylic acids, ketoacids, and $\alpha$ dicarbonyls in the tropical Indian aerosols, J. Geophys. Res., 115, D11302, doi:10.1029/2009JD012661, 2010.

Puxbaum, H., Caseiro, A., Sánchez-Ochoa, A., Kasper-Giebl, A., Claeys, M., Gelencsér, A., Legrand, M., Preunkert, S., and Pio, C.: Levoglucosan levels at background sites in Europe for assessing the impact of biomass combustion on the $\mathrm{Eu}$ ropean aerosol background, J. Geophys. Res., 112, D23S05, doi:10.1029/2006JD008114, 2007.

Ramanathan, V., Crutzen, P. J., Kiehl, J. T., and Rosenfeld, D.: Atmosphere - Aerosols, climate, and the hydrological cycle, Science, 294, 2119-2124, 2001.

Reid, J., Hobbs, P., Ferek, R., Blake, D., Martins, J., Dunlap, M., and Liousse, C.: Physical, chemical, and optical properties of regional hazes dominated by smoke in Brazil, J. Geophys. Res., 103, 32059-32080, 1998.

Rinaldi, M., Decesari, S., Carbone, C., Finessi, E., Fuzzi, S., Ceburnis, D., O’Dowd, C. D., Sciare, J., Burrows, J. P., Vrekoussis, M., Ervens, B., Tsigaridis, K., and Facchini, M. C.: Evidence of a natural marine source of oxalic acid and a possible link to glyoxal, J. Geophys. Res., 116, D16204, doi:10.1029/2011JD015659, 2011.

Sillanpää, S., Saarrikoski, S., Hillamo, R., Pennanen, A., Makkonen, U., Spolnik, Z., Grieken, R. V., Koskentalo, T., and Salonen, R.: Chemical composition, mass size distribution and sources analysis of long-range transported wildfire smokes in Helsinki, Sci. Total Environ., 350, 119-135, 2005.

Simoneit, B. R. T., Cox, R. E., and Standely, L. J.: Organic matter of the troposphere-IV: Lipids in Harmattan aerosols of Nigeria, Atmos. Environ., 22, 983-1004, 1988.

Simoneit, B. R. T., Kobayashi, M., Mochida, M., Kawamura, K., Lee, M., Lim, H.-J., Turpin, B. J., and Komazaki, Y.: Composition and major sources of organic compounds of aerosol particulate matter sampled during the ACE-Asia campaign, J. Geophys. Res., 109, D19S10, doi:10.1029/2004JD004598, 2004. 
Simoneit, B. R. T., Medeiros, P. M., and Didyk, B. M.: Combustion products of plastics for refuse burning in the atmosphere, Environ. Sci. Technol., 39, 6961-6970, 2005.

Stephanou, E. G. and Stratigakis, N.: Oxocarboxylic and $\alpha, \omega-$ dicarboxylic acids: Photooxidation products of biogenic unsaturated fatty acids present in urban aerosols, Environ. Sci. Technol., 27, 1403-1407, 1993.

Tanzania Meteorological Agency, TMA: Data obtained from the Tanzania Meteorological Agency, Sokoine University of Agriculture meteorological observatory, unpublished data, 2011.

United Republic of Tanzania, URT.: Ministry of energy and minerals, the national energy policy of Tanzania of 2003, 2003, available at: http://mem.go.tz/Resources/eLibrary/tabid/93/Default. aspx, last access: 20 February 2013.

Volkamer, R., Platt, U., and Wirtz, K.: Primary and secondary glyoxal formation from aromatics: Experimental evidence for the bicycloalkyl-radical pathway from benzene, toluene, and pxylene, J. Phys. Chem. A., 105, 7865-7874, 2001.

Wang, G., Kawamura, K., Watanabe, T., Lee, S., Ho, K., and Cao, J.: High loadings and source strengths of organic aerosols in China, Geophys. Res. Lett., 33, L22801, doi:10.1029/2006GL027624, 2006.
Wang, G., Kawamura, K., Cheng, C., Li, J., Cao, J., Zhang, R., Zhang, T., Liu, S., and Zhao, Z.: Molecular distribution and stable carbon isotopic composition of dicarboxylic acids, ketocarboxylic acids, and $\alpha$-dicarbonyls in size-resolved atmospheric particles from Xi'an city, China, Environ. Sci. Technol., 46, 4783-4791, 2012.

Wang, H., Kawamura, K., Ho, K. F., and Lee, S. C.: Low molecular weight dicarboxylic acids, ketoacids and dicarbonyls in the fine particles from a roadway tunnel: significant secondary production from the precursors in vehicular emissions, Environ. Sci. Technol., 40, 6255-6260, 2006.

Warneck, P.: In-cloud chemistry opens pathway to the formation of oxalic acid in the marine atmosphere, Atmos. Environ., 37, 2423-2427, 2003.

Yassaa, N., Meklati, B. Y., Cecinato, A., and Marino, F.: Organic aerosols in urban and waste landfill of Algiers metropolitan area: Occurrence and sources, Environ. Sci. Technol., 35, 306-311, 2001.

Zhang, T., Claeys, M., Cachier, H., Dong, S., Wang, W., Meanhant, W., and Liu, X.: Identification and Estimation of the Biomass Burning Contribution to Beijing Aerosol Using Levoglucosan as a Molecular Marker, Atmos. Environ., 42, 7013-7021, 2008. 